\title{
Reproductive endocrine disruption in smallmouth bass (Micropterus dolomieu) in the Potomac River basin: spatial and temporal comparisons of biological effects
}

\author{
Vicki S. Blazer • Luke R. Iwanowicz • \\ Holly Henderson • Patricia M. Mazik • \\ Jill A. Jenkins • David A. Alvarez • John A. Young
}

Received: 13 January 2011 /Accepted: 15 July 2011/Published online: 4 August 2011

(C) The Author(s) 2011. This article is published with open access at Springerlink.com

\begin{abstract}
A high prevalence of intersex or testicular oocytes (TO) in male smallmouth bass within the Potomac River drainage has raised concerns as to the health of the river. Studies were conducted to document biomarker responses both temporally and spatially to better understand the influence of normal physiological cycles, as well as water quality and land-use influences. Smallmouth bass were collected over a 2-year period from three tributaries of the Potomac River: the Shenandoah River, the South Branch Potomac and Conococheague Creek, and an out-of-basin reference site on the Gauley River. The prevalence of TO varied seasonally with the lowest prevalence observed in July, post-spawn. Reproductive maturity and/or lack of spawning the previous
\end{abstract}

\footnotetext{
V. S. Blazer $(\bowtie) \cdot$ L. R. Iwanowicz

National Fish Health Research Laboratory, U.S. Geological Survey, Leetown Science Center,

11649 Leetown Road,

Kearneysville, WV 25430, USA

e-mail: vblazer@usgs.gov
}

\section{H. Henderson}

West Virginia Cooperative Fish and Wildlife Research Unit, Division of Forestry and Natural Resources, West Virginia University,

Morgantown, WV 26506, USA

P. M. Mazik

U.S. Geological Survey, West Virginia Cooperative Fish and Wildlife Research Unit, Division of Forestry and Natural Resources, West Virginia University, Morgantown, WV 26506, USA spring, as well as land-use practices such as application of manure and pesticides, may influence the seasonal observations. Annual, seasonal, and site differences were also observed in the percentage of males with measurable concentrations of plasma vitellogenin, mean concentration of plasma vitellogenin in females, and plasma concentrations of $17 \beta$ estradiol and testosterone in both sexes. Bass collected in the South Branch Potomac (moderate to high prevalence of TO) had less sperm per testes mass with a lower percentage of those sperm being motile when compared to those from the Gauley River (low prevalence of TO). An inverse relationship was noted between TO severity and sperm motility. An association between TO severity and wastewater treatment

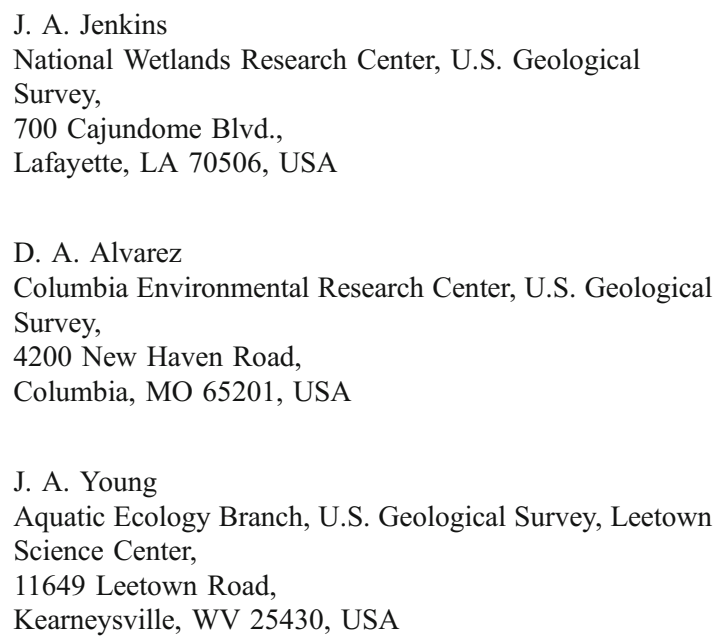


plant flow, percent of agriculture, total number of animal feeding operations, the number of poultry houses, and animal density within the catchment was observed.

Keywords Smallmouth bass · Potomac River . Reproductive biomarkers · Endocrine disruption

\section{Introduction}

Fish are widely used as indicators of aquatic ecosystem health. They are continually exposed to adverse water quality conditions, including chemical contaminants and potential pathogens, and act as integrators of such stressors. Consequently, biological impairment is often reflected by physiological and pathological indicators even when no impairments are predicted based on individual chemical indicators (Yoder and Rankin 1998; Adams 2002). Recurring fish mortalities during which a variety of microbial pathogens and parasites are observed have occurred in the Potomac drainage (Blazer et al. 2010). The subsequent observation of a high prevalence of intersex, specifically testicular oocytes (TO) in smallmouth bass Micropterus dolomieu in these same areas, has raised concerns among natural resource agencies, as well as the general public, regarding the health of the associated watershed. The Potomac is a source of drinking water for over five million people (Brayton et al. 2008), and hence, both aquatic organism health and potential human health effects are issues that need to be addressed. Numerous biological effects indicators have been developed and used in aquatic ecosystem health monitoring programs. Two widely used indicators of exposure to estrogenic, anti-estrogenic, or anti-androgenic endocrine-disrupting chemicals (EDC) are the presence of TO and other gonadal abnormalities, and the induction of vitellogenin (Vtg; an egg yolk precursor protein) in male fishes (Jobling et al. 1998; Denslow et al. 1999; Jones et al. 2000; Aerni et al. 2004; Wheeler et al. 2005). Based on results of wild fish surveys that have utilized these two indicators, smallmouth bass (SMB) appear to be sensitive to exposure to EDC (Baldigo et al. 2006; Blazer et al. 2007; Hinck et al. 2009; Iwanowicz et al. 2009). They are also a highly prized sport fish in many areas and so are economically important (Jenkins and Burkhead
1994). Consequently, SMB may be an important sentinel species, within the Potomac watershed and elsewhere.

We previously validated a semi-quantitative methodology for assessing TO occurrence and severity in male SMB and compared the prevalence and severity at selected sites within the Potomac drainage and nearby out-of-basin sites (Blazer et al. 2007). In that study, the prevalence of TO ranged from a low of $14 \%$ at out-of-basin sites to a high of $100 \%$ at sites in the Shenandoah River. Wastewater treatment plant (WWTP) effluents are considered major sources of complex estrogenic mixtures in the aquatic environment (Aerni et al. 2004; Thorpe et al. 2006). The combination of steroidal estrogens, xenoestrogens, and chemicals with anti-androgenic activity all contribute to the multicausal etiology of feminization of wild fishes (Jobling et al. 2009). A subsequent study in the Potomac drainage compared reproductive endpoints (including the presence of TO) and water quality, including estimated concentrations of more than 140 chemicals measured using integrated passive samplers deployed upstream and downstream of WWTP on two tributaries: the Monocacy River and Conococheague Creek (Alvarez et al. 2009; Iwanowicz et al. 2009). While some reproductive endpoints (gonadosomatic index, plasma Vtg in females) were depressed at downstream sites, a high prevalence of $\mathrm{TO}$ and the presence of plasma Vtg in male bass were observed at both upstream and downstream sites. These results indicated that sources, in addition to WWTP effluents, are likely influencing the reproductive physiology of bass within the Potomac drainage. It is currently unknown whether these findings are associated with reduced reproductive capacity (population effects), other reproductive abnormalities in male or female SMB, or with specific chemicals in the water, tissue, and/or sediment.

The objectives of this study were to revisit certain sites in the Potomac drainage at which TO had previously been documented in order to identify possible sources of estrogenic chemicals and to consider their presence in the context of land-use and reproductive endpoints. These endpoints included sperm quantity and quality, TO prevalence and severity, and plasma sex steroid hormone and vitellogenin concentrations in both sexes. In spring 2006 and 2007, biological endpoints were measured at sites within the Potomac drainage and a nearby reference 
river. The catchments above these sites represent varying intensities of agricultural, suburban/urban, and forested land use (Table 1). Seasonal comparisons of reproductive endpoints were also evaluated to obtain a better understanding of the environmental and physiological factors contributing to the presence of TO and plasma Vtg in male SMB.

\section{Materials and methods}

\section{Study sites}

Sites were selected throughout the Potomac drainage to represent a gradient of agricultural and urban/ suburban land use. An out-of-basin site on the Gauley River in the western part of West Virginia near Craigville was included as a reference. The Gauley River arises in Pocahontas County, WV, and flows into Webster County and then into the Ohio River (Fig. 1). Land use in the catchment above this site is primarily forested $(95.1 \%)$ with $3.9 \%$ developed and $0.5 \%$ agriculture (Table 1 ).

The South Branch of the Potomac River arises in Highland County, VA, flows north across the Virginia/ West Virginia border into Pendleton county, and continues northward into Grant County, WV. Here it forms a confluence with the North Fork of the South Branch at Cabins, WV, where it flows east to
Petersburg (site was downstream of Petersburg), into Hardy County, and then northeast to Moorefield. At Moorefield, the South Branch is joined by the South Fork South Branch Potomac River and runs north to Old Fields (Moorefield site). It passes into Hampshire County and continues north toward Romney and then to the northeast by Springfield and joins the North Branch to form the Potomac, just after Indian Rocks (Fig. 1). Land use in the catchments above the South Branch sites ranges from $3.8 \%$ to $3.9 \%$ developed, $15.2 \%$ to $16.4 \%$ agriculture, and $79.4 \%$ to $80.4 \%$ forested (Table 1).

Fish collections on the Shenandoah River were in Virginia and included sites on the South and North Forks. The North Fork begins in Rockingham County, flows through Shenandoah County (North Fork site, near Strasburg) into Warren County where it joins the South Fork to form the Shenandoah. The South Fork begins in Augusta County, flows through Rockingham (South Fork site near Elkton) and Page Counties, and into Warren County. For the seasonal comparisons, bass were also collected at a site on the mainstem Shenandoah north of the confluence of the North and South Fork in Clarke County, VA (Fig. 1). Land use in the catchments above the Shenandoah sites ranges from $6.6 \%$ to $11.1 \%$ developed, $32.7 \%$ to $35.9 \%$ agriculture, and $52.6 \%$ to $60.2 \%$ forested (Table 1 ).

Conococheague Creek originates in Franklin county, Pennsylvania and flows south through the city of

Table 1 Characteristics of the catchments above the smallmouth bass $M$. dolomieu collection sites

\begin{tabular}{|c|c|c|c|c|c|c|c|}
\hline \multirow[t]{2}{*}{ Site } & \multirow{2}{*}{$\begin{array}{l}\text { Human } \\
\text { population }^{\mathrm{a}}\end{array}$} & \multirow{2}{*}{$\begin{array}{l}\text { Catchment } \\
\text { area (ha) }\end{array}$} & \multirow{2}{*}{$\begin{array}{l}\text { Stream } \\
\text { length }(m)^{b}\end{array}$} & \multirow{2}{*}{$\begin{array}{l}\text { Stream } \\
\text { order }^{c}\end{array}$} & \multicolumn{3}{|c|}{ Percent land cover ${ }^{\mathrm{d}}$} \\
\hline & & & & & Developed & Agriculture & Forest \\
\hline Gauley River & 1,157 & $18,698.1$ & $133,458.6$ & 3 & 3.9 & 0.5 & 95.1 \\
\hline South Branch Petersburg & 15,067 & $219,944.4$ & $1,584,013.9$ & 7 & 3.8 & 16.4 & 79.4 \\
\hline South Branch Moorefield & 20,940 & $315,074.0$ & $2,379,186.9$ & 5 & 3.9 & 15.2 & 80.4 \\
\hline South Branch Springfield & 29,003 & $382,132.1$ & $3,105,675.1$ & 7 & 3.8 & 15.2 & 80.4 \\
\hline Shenandoah North Fork & 67,426 & $241,004.3$ & $1,227,982.3$ & 5 & 6.6 & 32.7 & 60.2 \\
\hline Shenandoah South Fork & 187,303 & $336,559.1$ & $1,835,355.3$ & 5 & 11.1 & 35.9 & 52.6 \\
\hline Shenandoah Mainstem & 316,759 & $734,170.1$ & $3,739,595.0$ & 6 & 9.2 & 32.6 & 57.6 \\
\hline Conococheague Creek (lower) & 100,239 & $145,446.0$ & $1,117,871.5$ & 5 & 12.4 & 50.3 & 35.8 \\
\hline
\end{tabular}

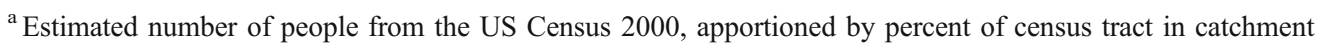

${ }^{\mathrm{b}}$ Meters of stream from National Hydrography Dataset + dataset

${ }^{\mathrm{c}}$ Strahler stream order, maximum

${ }^{\mathrm{d}}$ From national land cover data 2001 database
} 
Fig. 1 Location of the sampling sites for smallmouth bass $M$. dolomieu collected in 2006-2007.

Catchments upstream of the sampling sites (black dot) are outlined and shown in white. Insert illustrates the location of the Potomac River catchments within Chesapeake Bay drainage area

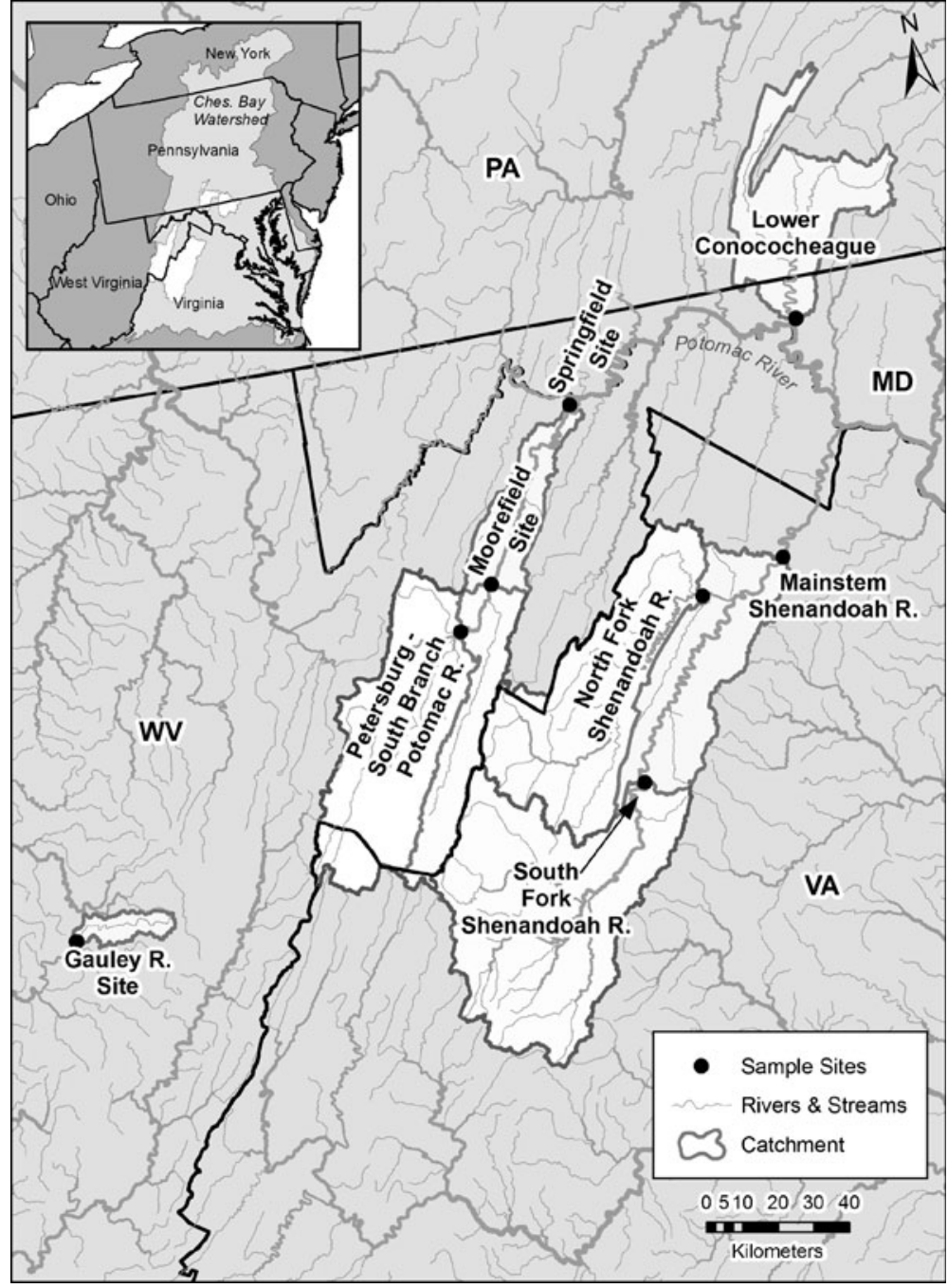

Williamsport (Washington County, MD) to the Potomac River (Fig. 1). The site on Conococheague Creek was below a WWTP, and land use in the catchment above this site is $12.4 \%$ developed, $50.3 \%$ agriculture, and $35.8 \%$ forested (Table 1).

\section{Landscape analyses}

Landscape data associated with fish collection sites included land use, animal feeding operations (AFO), point source discharges, and human population. Landscape summaries were generated from publicly available data sources, or developed from interpretations of publicly available imagery. Data were summarized by defining the hydrologic units (catchments) draining to the study sites using the National
Hydrography Dataset (www.horizon-systems.com/ nhdplus). Stream length and Strahler stream order were also acquired from this dataset, and land-use data were acquired from the 2001 National Land Cover Dataset (www.mrlc.gov). Point source discharges were summarized using the US Environmental Protection Agency (EPA) Permit Compliance System (PCS) database as compiled for the Better Assessment Science Integrating Point and Nonpoint Sources (BASINS) program (www.epa.gov/ waterscience/basins). The number of facilities and permitted mean annual discharge (million gallons per day) for WWTP facilities was determined using the PCS database. Human population and density information were derived from the US Census Bureau's 2000 decennial census, by census tract and appor- 
tioned to catchments by proportions of tract within a catchment draining to a study site.

Aerial photographic images available through the Google Earth computer program were interpreted to count the number of AFO. Poultry houses are easily distinguished from high-resolution aerial photography by the long, narrow metallic roofs. The location of each poultry house was mapped as a point, and the number of points in each catchment draining to a study location was calculated for poultry AFO. Similarly, the locations of cattle AFO (dairies, feed lots) are distinguishable from high-resolution aerial images by characteristic clustering of loafing lots, milking barns, and cattle trails (often with observable animals). Total animal numbers by catchment were derived by summarizing the animal crop numbers per county (2007 USDA Agricultural Census) and dividing these totals by the mapped proportion of each county in a catchment. Animal density was calculated by dividing the total number of animals by the catchment area.

Fish collections

All fish were captured by boat electroshocking. The goal was to collect ten mature SMB ( $>200 \mathrm{~mm}$ total length) of each sex. From March 29 to 30, 2006, a total of $20 \mathrm{SMB}$ were collected at each of the three sites on the Shenandoah: the South Fork, North Fork, and mainstem (Fig. 1). From May 16 to 18, 2006, SMB were collected from the three sites on the South Branch and one site on the Gauley River (Fig. 1). There were a total of 20 SMB collected at each of the South Branch sites and a total of 17 SMB collected in the Gauley. For seasonal comparisons of TO prevalence and severity and plasma Vtg concentrations, SMB were also collected from the South Fork, North Fork, and mainstem Shenandoah, July 25-28 and October 24-27, 2006.

In spring 2007, we attempted to collect SMB from seven sites on the Potomac drainage and one site on the Gauley when they were on their spawning nests at each site. These included two of the South Branch sites (Petersburg, Springfield), the South Fork and North Fork Shenandoah sites, sites upstream and downstream of a WWTP on Conococheague Creek, and a site on the Monocacy River. Unfortunately, inadequate sample sizes were obtained from the upstream Conococheague and Monocacy sites, and these data are not included in the analyses. Bass were captured on March 26 and 27 from the Shenandoah River, May 3-9 in the South Branch and Conococheague and May 24 from the Gauley River.

\section{Fish processing}

Fish were held in large, aerated buckets of river water until processed (less than $1 \mathrm{~h}$ ). Fish were euthanized with tricaine methanesulfonate (Finquel, Argent Laboratories, Redmond, WA) and bled from the caudal vein using heparinized 3-cc syringes with 23-gauge needles. Blood was placed in heparinized Vacutainer ${ }^{\circledR}$ tubes containing $62 \mathrm{U}$ sodium heparin (Fisher Scientific, Pittsburgh, PA) and held on wet ice for less than $4 \mathrm{~h}$. Blood was centrifuged within $4 \mathrm{~h}$ of collection for $10 \mathrm{~min}$ at $1,000 \times \mathrm{g}$ and $4^{\circ} \mathrm{C}$ for plasma separation. Plasma was removed, aliquoted into cryovials, and stored at $-80^{\circ} \mathrm{C}$ until assayed for $\mathrm{Vtg}$ or reproductive hormones. Each fish was weighed (to the nearest grams), measured (to the nearest millimeters), observed for gross lesions and abnormalities, and liver and gonad removed and weighed to the nearest $0.01 \mathrm{~g}$. Otoliths were removed and used for aging the fish. Condition factor (Ktl) was calculated by the formula: ((Body weight-Gonad weight in gm)/ length ${ }^{3}$ in $\left.\mathrm{mm}\right) \times 10^{5}$.

During the May 16-18, 2006 collections, one lobe of the testes was fixed for histology, and one was placed in a 15-ml conical tube containing Hank's balanced salt solution (HBSS) for sperm quality analysis. Tubes were wrapped in foil, placed on wet ice, and shipped overnight to the USGS National Wetlands Research Center, Lafayette, LA. Pieces of gonad for histological evaluation were fixed in ZFix $^{\text {TM }}$ (Anatech Ltd., Battle Creek, MI).

Reproductive endpoints

Gonadosomatic index (GSI) was calculated as follows: (gonad weight/body weight) $\times 100$. Plasma Vtg concentrations were measured using a direct enzymelinked immunosorbent assay (ELISA) with monoclonal antibody $3 \mathrm{G} 2$ at the University of Florida, Center for Human and Environmental Toxicology as described by Denslow et al. (1999). Plasma samples were diluted 1:200, 1:10,000, 1:100,000, and 1:1,000,000 with PBSZ-AP (10 mM phosphate, $150 \mathrm{mM} \mathrm{NaCL}, 0.02 \%$ azide, $10 \mathrm{KUI} / \mathrm{ml}$ Aprotinin, 
$\mathrm{pH}$ 7.6). Species-specific Vtg standards $(0,0.005$, $0.01,0.02,0.04,0.06,0.08,0.10,0.20,0.40,0.60$, $0.80,1.0 \mu \mathrm{g} / \mathrm{ml})$ containing $1: 200,1: 10,000$, $1: 100,000$, and $1: 1,000,000$ male plasma (in PBSZAP) were added to account for matrix effects. Samples and standards were loaded onto a 96-well ELISA plate in triplicate and stored overnight at $4{ }^{\circ} \mathrm{C}$ in a humidified chamber. The following day the plates were washed four times with PBSZ, blocked with $1 \%$ bovine serum albumin (BSA)/TBSTZ-AP (1\% BSA in $10 \mathrm{mM}$ Tris, $150 \mathrm{mM} \mathrm{NaCL}, 0.05 \%$ Tween, $0.02 \%$ azide, $10 \mathrm{KIU} / \mathrm{ml}$ Aprotinin, $\mathrm{pH}$ 7.6) for $2 \mathrm{~h}$ at room temperature and then rewashed four times with PBSZ. The monoclonal antibody was loaded into wells on each plate, and plates were stored overnight at $4{ }^{\circ} \mathrm{C}$ in a humidified chamber. The following day plates were washed and the biotinylated secondary antibody (goat anti-mouse IgG-biotin) was added to each well at 1:1,000 dilution in 1\% BSA/TBSTZ-AP and incubated at room temperature for $2 \mathrm{~h}$. Plates were washed and streptavidin-alkaline phosphatase was added at 1:1,000 dilution in 1\% BSA/TBSTZ-AP and incubated for $2 \mathrm{~h}$ at room temperature. After a final wash, color was developed by adding $1 \mathrm{mg} / \mathrm{ml} p$-nitrophenyl phosphate in carbonate buffer $(0.03 \mathrm{M}$ carbonate, $2 \mathrm{mM} \mathrm{MgCl}_{2}$, $\mathrm{pH}$ 9.6) and measured using an ELISA plate reader (SpectraMax Plus 384, Molecular Devices Inc., Sunnyvale, CA) at $405 \mathrm{~nm}$. Concentrations of the unknowns were determined from the standard curves and using the Softmax Pro TM Program (Molecular Devices). The limit of detection was $0.001 \mathrm{mg} / \mathrm{ml}$. Inter- and intra-assay variabilities are $<10 \%$.

Plasma hormone concentrations of $17 \beta$-estradiol (E2) and testosterone ( $\mathrm{T}$ ) were measured using radioimmunoassay according to Sower and Schreck (1982). Plasma samples were extracted twice in a tenfold excess of diethyl ether, blown to dryness, and solubilized in $200 \mu \mathrm{l}$ of room temperature PG buffer $(0.1 \%$ knox gelatin in phosphate-buffered saline). One hundred microliters of anti-estradiol antiserum (anti$17 \beta$-estradiol Ab-\#244 anti-estradiol-6-BSA) purchased from the lab of Gordon Niswender (Colorado State University, Fort Collins, CO) diluted 1:65,000 in PG buffer or anti-testosterone antiserum (R156/7) purchased from Coralie Munroe (University of California, Davis, CA) diluted 1:30,000 in PG buffer was added to each sample tube, vortexed, and incubated at room temperature for $30 \mathrm{~min}$. The same volume of PG buffer was added to tubes designated to determine non-specific background and total counts per minute (CPM). Following incubation, $100 \mu \mathrm{l}$ of tritiated $17 \beta$-estradiol or testosterone $(5,000 \mathrm{CPM}$ in PG buffer) was added to all tubes, vortexed, and incubated at room temperature for 60 or $30 \mathrm{~min}$, respectively. Samples were immediately cooled in an ice bath for $30 \mathrm{~min}$, and $500 \mu \mathrm{l}$ of ice-cold charcoal-dextran solution $(0.63 \%$ alkaline charcoal and $0.4 \%$ dextran in PG buffer) was added. Samples were vortexed, incubated on ice for $15 \mathrm{~min}$, and centrifuged at $2,200 \times \mathrm{g}$ for $20 \mathrm{~min}$ at $4{ }^{\circ} \mathrm{C}$. The supernatant was then decanted into scintillation vials containing $4 \mathrm{ml}$ of OptiPhase HiSafe 2 scintillation fluid (Perkin Elmer, Waltham, MA) and mixed by inversion. Sample CPM were measured using Tri Carb Liquid Scintillation Counter (Perkin Elmer), and mean sample CPM was determined over an 8-min integration time. All samples were run in duplicate, and plasma estradiol values were interpolated from a standard curve using curve fitting feature of Prism for Windows 4.03 (GraphPad Software Inc., La Jolla, CA). Sample values were rejected and reevaluated if the coefficient of variation between duplicate tubes exceeded $10 \%$.

Five to seven cross sections were taken along the gonads of both male and female fish and processed for histological evaluation, provided enough tissue was present. The tissue pieces were embedded in paraffin, sectioned with a microtome at $6 \mu \mathrm{m}$, and stained with hematoxylin and eosin (Luna 1992). Sections were examined microscopically to confirm sex, determine the stage of gonad development, and to document intersex and other microscopic abnormalities (Blazer 2002; Dietrich and Krieger 2009). Oocyte stages were scored as stage 1 -immature (nucleolar), stage 2-early vitellogenic (corticol alveolar), stage 3-mid-vitellogenic (yolk droplet), stage 4 -mature (yolk begins to hydrate), and stage 5postovulatory follicles. Male gonad stage was scored as stage 1 -exclusively immature stages (spermatogonia to spermatids); stage 2-predominantly immature stages, some sperm may be present; stage 3approximately equal portions of spermatocytes, spermatids, and spermatozoa; stage 4-primarily spermatozoa; and stage 5-post-spawn.

Intersex in bass gonads presents as immature oocytes within the testes of male fish (Fig. 2a). The severity index for bass intersex (Blazer et al. 2007) is 
based on the number and distribution of oocytes within the testes. Focal distribution (score 1) is a single oocyte within the field of view of testicular tissue (scores determined at a magnification of $\times 200$ ). Diffuse distribution (score 2) is more than one oocyte in the field of view, but with no physical association with neighboring oocytes. Cluster distribution (score 3 ) is more than one but less than five physically associated oocytes in a field of view. Zonal distribution (score 4) is five or more physically associated oocytes or numerous clusters of oocytes within a field of view. The scores for each (5-7) cross section were averaged, yielding the mean score for each fish.

For sperm analysis, testes were minced to obtain individual cells, stored in HBSS, diluted if necessary, and aliquots of the cells were analyzed by flow cytometry (FACSCalibur ${ }^{\circledR}$, Becton Dickinson Immu- nocytometry Systems, Jan Jose, CA) for counts, stage of maturity, and viability as described by Jenkins et al. (2009). Motility was assessed with computer-assisted semen analysis (CASA) using a $25-\mu 1$ aliquot of activated milt (Jenkins et al. 2011) in a chambered slide (Leja Products, Nieuw-Vennep, the Netherlands) and viewed with phase microscopy using an Olympus BX41 microscope (Olympus America, Central Valley, PA) at $\times 200$ magnification. Total and progressive motility, curvilinear velocity, and straight-line velocity were analyzed using SpermVision, Version 3.0 software (Minitube of America Inc., Verona, WI) with the following settings: area of cell identification $8 \times$ $30 \mu^{2}$ and field of view $20 \mu \mathrm{m}$. Cells with an average orientation change of head $<9.5^{\circ}$ were classified as immotile while those with distance straight line $<6 \mu \mathrm{m}$ were classified as locally motile.

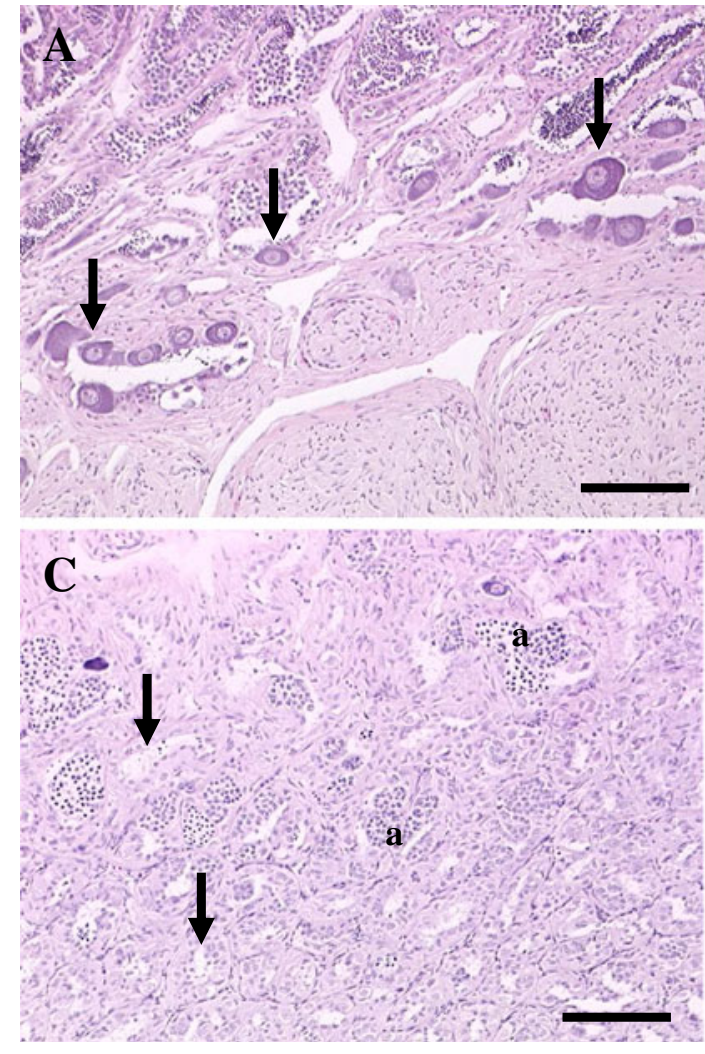

Fig. 2 Microscopic appearance of testicular tissue of smallmouth bass $M$. dolomieu collected in the Potomac drainage. a Oocytes (arrows) within the epithelium lining testicular tubules. Scale bar $=50 \mu \mathrm{m}$. b Oocytes (arrows) within the lumen of testicular tubules. Scale bar $=20 \mu \mathrm{m}$. c Testes of smallmouth bass collected during the summer with no apparent residual

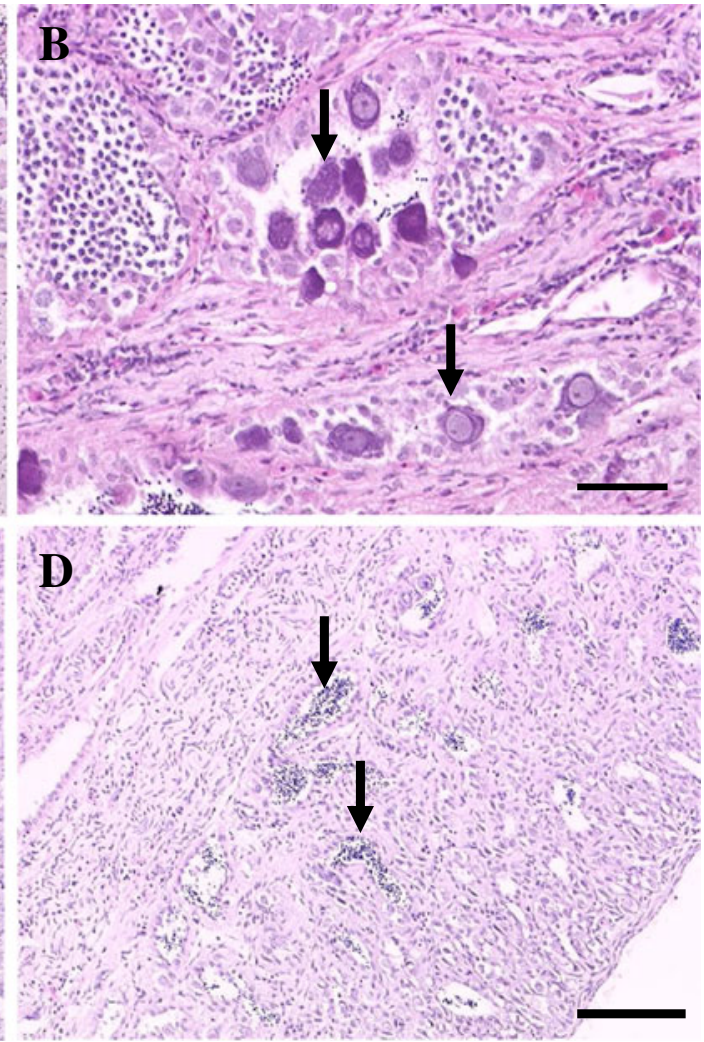

sperm within the tubules (arrows). Nests of immature stages (a), spermatocytes, and spermatids are evident. Scale bar= $100 \mu \mathrm{m}$. d Testes of smallmouth bass collected during the summer with residual sperm (arrows) in some tubules. Scale bar $=100 \mu \mathrm{m}$. H\&E stain 
A linear classification was assigned if straightness (velocity straight line/velocity average path) $>0.9 \mu \mathrm{m} / \mathrm{s}$ and linearity (LIN) $>0.5$, whereas a non-linear classification was assigned if straightness $<0.9$ and LIN $<0.5$. Cells with a distance average path (micrometers)/radius $>3$ and $\mathrm{LIN}<0.5$ were classified as curvilinear.

Total estrogenicity of water samples

During spring 2007, polar organic chemical integrative samplers (POCIS) were deployed prior to the fish collections at the South Fork Shenandoah, Conococheague Creek, South Branch Petersburg and Springfield, and Gauley River. Samplers were also deployed at multiple sites in the North Fork of the Shenandoah, the mainstem Shenandoah site, and others during spring 2007 (Alvarez et al. 2008a, b). Extracts were prepared from the samplers and used to assess total estrogenicity utilizing the yeast estrogen screen (YES) as described by Alvarez (2008c). The extracts from the passive samplers deployed for this specific study were also analyzed for total estrogenicity at the USGS National Fish Health Research Laboratory in Leetown, WV using the bioluminescent or bioluminescent yeast estrogen screen (BLYES) assay (Sanseverino et al. 2009). The bioluminescent strain of yeast was maintained in a dormant stage at $4^{\circ} \mathrm{C}$ in modified yeast minimal media (YMM leu-, ura-; Routledge and Sumpter 1996). Preparation of the screening assay involved the expansion of the strain BLYES to early stationary phase in $\mathrm{YMM} \mathrm{leu}^{-}$, ura- at $30^{\circ} \mathrm{C}$ on a rotary shaker to an appropriate $\mathrm{OD}_{600}$ of 0.750 . The assay was performed in sterile, clear-bottom, black polystyrene 96-well assay plates (Costar, Corning Incorporated, Corning, NY). Sample extracts previously solubilized in methanol were diluted to $10 \%$ in YMM, and $100 \mu \mathrm{l}$ of the diluted sample was added to triplicate wells. An equal volume of yeast in YMM was added to each well, resulting in a final sample dilution of 5\%. All assay plates included a 12-point standard curve consisting of $17 \beta$-estradiol and blanks. Blanks and standards all contained 5\% methanol to account for possible solvent effects. Plates were incubated in the dark at $30^{\circ} \mathrm{C}$ for $6 \mathrm{~h}$ on an orbital shaker. Luminescence was quantified using a SpectraFluor Plus plate reader (Tecan Group LTD, Durham, NC) in luminescence mode (1 s integration time/well, gain 180). Quantitation limit was $0.31 \mathrm{ng} / \mathrm{l}$ estradiol equivalents.
Statistical analyses

All quantitative data were analyzed by one-way analysis of variance (ANOVA). If assumptions of normality were not met, a nonparametric ANOVA was used followed by the Kruskal-Wallis test for significance. Fisher's exact test was used to compare ordinal data sets (measurements reported as a percent). Pearson's correlation analysis was performed to determine if TO severity was a significant causative factor in sperm quality differences among sites and also if TO prevalence or severity was associates with specific land-use characteristics. All statistics are reported at $\alpha=0.05$ and were performed using SYSTAT version 9.0 (SPSS Inc., Chicago, IL) or GraphPad InStat version 3.0 (GraphPad Software Inc.).

\section{Results}

Morphometric parameters-spring 2006

Smallmouth bass collected in spring 2006 from the South Branch ranged in age from 2 to 5 years at Petersburg and Moorefield and from 2 to 8 years at Springfield. Bass collected at the Gauley were not aged. Within the South Branch, bass collected at Springfield were older than those at Moorefield. Bass from the Gauley were significantly shorter in length and lighter in weight than those from the South Branch, but among South Branch sites, there were no significant differences in length or weight. There was no difference among the four sites in condition factor (Table 2).

Smallmouth bass were also collected from the Shenandoah River in spring 2006, however in March rather than May, so were compared separately. Bass from the North Fork ranged in age from 2 to 5 years. No age data were available for those collected from the South Fork. There was no difference between bass collected at the two sites for any morphometric parameters (Table 2).

Reproductive endpoints—-spring 2006

With the exception of two immature 2-year-old female bass (stage 1) from Moorefield, all females had measureable levels of $\mathrm{Vtg}$ during this period of the reproductive cycle. Plasma concentrations ranged from 0.333 to $3.317 \mathrm{mg} / \mathrm{ml}$ in bass collected from 
Table 2 Morphometric comparisons of smallmouth bass M. dolomieu collected at selected sites in the Potomac drainage and the Gauley River in spring 2006

\begin{tabular}{llclll}
\hline Site & $n$ & Age (years) & Length (mm) & Weight (gm) & Condition factor (Ktl) \\
\hline Gauley & 17 & No data & $215.0(18.9) \mathrm{a}$ & $120.4(32.7) \mathrm{a}$ & $1.18(0.07)$ \\
Petersburg South Branch & 20 & $3.1(1.1) \mathrm{ab}$ & $260.3(48.6) \mathrm{b}$ & $234.9(138.4) \mathrm{b}$ & $1.20(0.09)$ \\
Moorefield South Branch & 20 & $2.9(1.1) \mathrm{a}$ & $258.0(40.4) \mathrm{b}$ & $234.2(118.1) \mathrm{b}$ & $1.26(0.09)$ \\
Springfield South Branch & 20 & $4.2(1.7) \mathrm{b}$ & $264.3(56.6) \mathrm{b}$ & $266.1(177.1) \mathrm{b}$ & $1.26(0.09)$ \\
South Fork Shenandoah & 20 & No data & $283.6(38.1)$ & $322.8(136.2)$ & $1.29(0.09)$ \\
North Fork Shenandoah & 20 & $(1.0)$ & $289.4(42.5)$ & $333.3(164.2)$ & $1.23(0.13)$ \\
\hline
\end{tabular}

Data are presented as means (standard deviation). Values within the same column denoted with the same letter are not significantly different. If no statistical differences were identified among sites for a given parameter, annotation was omitted to facilitate readability. The Shenandoah sites were compared separately due to different sampling times. The threshold for statistical significance was $p \leq 0.05$

the South Branch and the Gauley. There were no statistical differences in mean female plasma Vtg among sites within the South Branch and the Gauley (Table 3). All female bass from the Shenandoah had measurable Vtg and concentrations ranged from 0.021 to $8.137 \mathrm{mg} / \mathrm{ml}$. There were significant differences between the two sites for circulating Vtg concentrations and GSI with bass from the South Fork being higher (Table 3).

Vitellogenin was also detected in $26.7 \%$ and $18.2 \%$ of male SMB collected at the Petersburg and Moore- field sites, respectively. Of the males with detectable $\mathrm{Vtg}$, maximum concentrations of $0.059 \mathrm{mg} / \mathrm{ml}$ in fish from Petersburg and $0.130 \mathrm{mg} / \mathrm{ml}$ in those from Moorefield were observed. No Vtg was measurable in males collected from the Gauley or in those collected at Springfield. In SMB collected from the Shenandoah River, Vtg was detected in $50 \%$ of the males from the North Fork site, but none from those collected in the South Fork. The highest concentration measured in male SMB from the North Fork was $0.012 \mathrm{mg} / \mathrm{ml}$, and there was no difference among sites

Table 3 Reproductive biomarkers of smallmouth bass $M$. dolomieu collected at selected sited in the Potomac drainage and the Gauley River in spring 2006

\begin{tabular}{|c|c|c|c|c|c|}
\hline Site & Sex & Sample size & Gonadosomatic index & Intersex severity & Vitellogenin $^{\mathrm{a}}(\mathrm{mg} / \mathrm{ml})$ \\
\hline \multirow[t]{2}{*}{ Gauley } & $\mathrm{F}$ & 7 & No data & $0.02(0.06) \mathrm{a}$ & $1.076(0.400)$ \\
\hline & $\mathrm{M}$ & 10 & $0.59(0.24)$ & & $\mathrm{BD}$ \\
\hline \multirow[t]{2}{*}{ Petersburg South Branch } & $\mathrm{F}$ & 5 & No data & $0.75(0.92) b$ & $1.782(1.366)$ \\
\hline & M & 15 & $0.61(0.14)$ & & $0.021(0.025)$ \\
\hline \multirow[t]{2}{*}{ Moorefield South Branch } & $\mathrm{F}$ & 9 & No data & $0.50(0.50) \mathrm{ab}$ & $1.558(0.900)$ \\
\hline & M & 11 & $0.71(0.24)$ & & $0.093(0.052)$ \\
\hline \multirow[t]{2}{*}{ Springfield South Branch } & $\mathrm{F}$ & 7 & No data & $1.14(0.76) b$ & $0.863(0.357)$ \\
\hline & $\mathrm{M}$ & 13 & $0.52(0.13)$ & & $\mathrm{BD}$ \\
\hline \multirow[t]{2}{*}{ South Fork Shenandoah } & $\mathrm{F}$ & 7 & $5.88(2.30) \mathrm{A}$ & $1.62(0.65) \mathrm{A}$ & $6.014(2.457) \mathrm{A}$ \\
\hline & $\mathrm{M}$ & 13 & $0.43(0.28)$ & & $\mathrm{BD}$ \\
\hline \multirow[t]{2}{*}{ North Fork Shenandoah } & $\mathrm{F}$ & 10 & $2.77(1.50) \mathrm{B}$ & $0.62(0.40) \mathrm{B}$ & $2.861(2.574) \mathrm{B}$ \\
\hline & $\mathrm{M}$ & 10 & $0.51(0.19)$ & & $0.007(0.003)$ \\
\hline
\end{tabular}

Data presented as means (standard deviation). Statistical comparisons were made between fish of the same sex. The Shenandoah sites were compared separately because of different sampling times. Values within a column denoted with the same letter are not significantly different. If no statistical differences were identified between sites for a given parameter, annotation was omitted to facilitate readability. The threshold for statistical significance was $p \leq 0.05$

$B D$ below detection

${ }^{a}$ Vitellogenin means include only those samples that had measureable concentrations 
in mean concentration of those with detectable Vtg (Table 3; Fig. 3a).

The prevalence of TO was the lowest in fish collected from the Gauley at a rate of $10 \%$ affected (Fig. 3a). In the South Branch, the severity of TO was the greatest in SMB from Springfield, and SMB from both Springfield and Petersburg had higher severities than those collected at the Gauley (Table 3). In the Shenandoah, $100 \%$ of the males from the South Fork and $80 \%$ of those from the North Fork had TO (Fig. 3a). The severity of TO was the highest in the testes collected from the South Fork (Table 3).

Sperm quality—spring 2006

Male SMB collected from the Gauley had statistically more sperm per testis mass than those at Petersburg

A

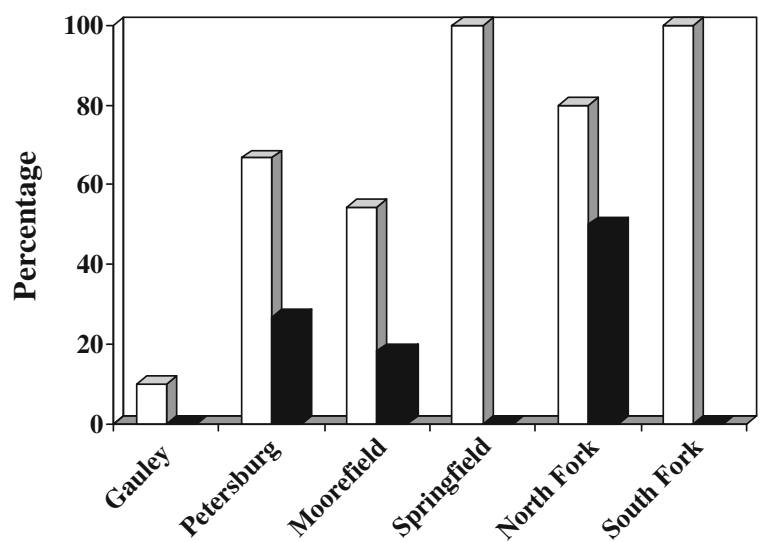

B

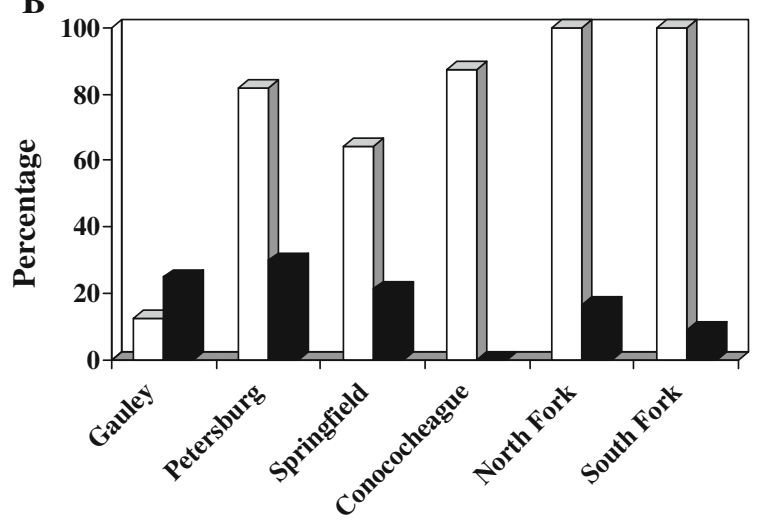

Sites

Fig. 3 Percentage of male smallmouth bass M. dolomieu with testicular oocytes (white bars) and plasma vitellogenin (black bars) collected in the Gauley River and selected sites within the Potomac River drainage. a 2006. b 2007 and Springfield, while sperm counts from SMB collected at Moorefield were intermediate (Table 4), although there was no difference among sites for GSI (Table 3 ). Sperm viability (range $=93 \%$ to $97 \%$ ) was not statistically different among sites (data not shown). The proportions of mature sperm forms in testes were similar among all sites, suggesting that seasonal reproductive maturation due to differences in geographic location was not a factor. The percent of sperm demonstrating motility was significantly higher in SMB collected from the Gauley (86.5\%) than all South Branch sites (ranged from 16.8\% to $29.0 \%$ ). Similarly, sperm from SMB collected in the Gauley had significantly higher progressive motility (forward movement) than sperm from SMB collected in the South Branch (Table 4). No differences were found to exist in curvilinear velocity and straight-line velocity of the sperm (data not shown). Subsequent regression analysis indicated an inverse, weak but significant relationship between TO severity and percent motile sperm $\left(R^{2}=0.32, p<0.001\right)$.

Morphometric parameters-spring 2007

Smallmouth bass collected in the South Branch ranged in age from 3 to 10 years of age, in Conococheague Creek from 2 to 4 years, and in the Shenandoah from 2 to 7 years. Ages were not available for SMB collected from the Gauley. The SMB from Conococheague Creek were younger than those from all sites except the North Fork Shenandoah. Bass from North Fork Shenandoah and Conococheague also had the highest condition factors. Bass from the Gauley and Conococheague Creek were smaller (length and weight) than those from the other sites (Table 5).

Reproductive endpoints_-spring 2007

One immature 2-year-old female bass from the South Fork Shenandoah, one from the Gauley (age unknown), and six immature 2-year-olds (stage 1) from Conococheague Creek had no measurable Vtg. The GSI at the Shenandoah sites were similar to the Gauley, higher than the Conocheague, and lower than the South Branch sites (Table 6).

The percentage of male SMB with measurable Vtg ranged from 0 at Conocheague Creek to $30 \%$ at Petersburg (Fig. 3b). The mean concentration of those 
Table 4 Sperm characteristics of smallmouth bass M. dolomieu spring 2006

\begin{tabular}{lrcccc}
\hline Site & $n$ & Count $\left(1 \times 10^{7}\right)$ & \% Mature & \% Total motility & \% Progressive motility \\
\hline Gauley & 10 & $10.01(9.00) \mathrm{a}$ & $63.54(17.33)$ & $86.48(6.91) \mathrm{a}$ & $27.07(15.88) \mathrm{a}$ \\
Petersburg South Branch & 9 & $5.32(4.04) \mathrm{b}$ & $60.32(15.69)$ & $28.97(38.96) \mathrm{b}$ & $6.63(6.31) \mathrm{b}$ \\
Moorefield South Branch & 9 & $7.86(6.40) \mathrm{a}, \mathrm{b}$ & $51.34(15.07)$ & $16.81(15.35) \mathrm{b}$ & $13.07(11.32) \mathrm{b}$ \\
Springfield South Branch & 10 & $3.74(3.86) \mathrm{b}$ & $59.33(10.87)$ & $17.47(15.46) \mathrm{b}$ & $12.48(10.75) \mathrm{b}$ \\
\hline
\end{tabular}

Data presented as means (standard deviation). Values within a column denoted with the same letter are not significantly different. If no statistical differences were identified among sites for a given parameter, annotation was omitted to facilitate readability. The threshold for statistical significance was $p \leq 0.05$

with measurable amounts was not different among sites (Table 6), nor were there any significant differences among the sites when all the data (non-detects as zeros) were used in the analyses. Most Vtg concentrations in males were below $0.050 \mathrm{mg} / \mathrm{ml}$; however, within the South Branch, there were three male fish with concentration above $0.400 \mathrm{mg} / \mathrm{ml}$ (one from Petersburg and two from Springfield) and two above $0.100 \mathrm{mg} / \mathrm{ml}$ (from Petersburg). Males with TO were found at all sites, and the prevalence ranged from $12.5 \%$ (Gauley) to $100 \%$ (Fig. 3b). The highest prevalence was noted in the Shenandoah, followed by Conocheague Creek and the South Branch sites. The Gauley had the lowest prevalence with only one male bass having TO. Intersex severity was the lowest at the Gauley and Springfield sites and the highest in the Shenandoah (Table 6). Gonadosomatic indices were the lowest in male SMB from the Gauley and Shenandoah sites and the highest in those from Conocheague Creek (Table 6).

Plasma concentrations of estradiol and testosterone were measured in SMB collected in 2007. There was a significant difference $(p=0.0014)$ in plasma estradiol concentrations of female SMB, but no difference among males (Fig. 4). Females from the Gauley and the two South Branch sites had the highest mean concentrations while those from the Shenandoah were intermediate and females from the Conococheague sites had lower mean concentrations (Fig. 4a). Testosterone concentrations in the female SMB were also significantly different $(p=0.0054)$ and showed the same trend among sites as estradiol (Fig. 5a). Male plasma testosterone concentrations differed among sites $(p<0.001)$ with SMB from the Gauley and South Branch sites having the highest concentrations, those from the Conococheague being intermediate, and those from the Shenandoah having the lowest concentrations (Fig. 5b).

The estrogen/testosterone (E/T) ratio which normalizes the two sex hormones within an individual to each other was calculated. Males typically have a ratio of less than 1.0 while females are greater than 1.0. A previous study with SMB suggested 1.4 as a conservative upper threshold for normal males and

Table 5 Morphometric characteristics of smallmouth bass $M$. dolomieu collected at selected sited in the Potomac drainage and the Gauley River in spring 2007

\begin{tabular}{lcllll}
\hline Site & Sample size & Age years & Length (mm) & Weight (gm) & Condition factor Ktl \\
\hline Gauley & 17 & ND & $230.1(33.0) \mathrm{a}$ & $147.2(59.2) \mathrm{a}$ & $1.13(0.06) \mathrm{a}$ \\
Petersburg South Branch & 18 & $4.1(1.9) \mathrm{a}$ & $282.9(60.7) \mathrm{ab}$ & $311.6(255.9) \mathrm{b}$ & $1.16(0.09) \mathrm{a}$ \\
Springfield South Branch & 19 & $4.7(1.3) \mathrm{a}$ & $298.8(52.8) \mathrm{b}$ & $318.4(177.9) \mathrm{b}$ & $1.14(0.10) \mathrm{a}$ \\
South Fork Shenandoah & 20 & $3.6(1.0) \mathrm{a}$ & $288.3(41.9) \mathrm{b}$ & $316.6(167.1) \mathrm{b}$ & $1.19(0.11) \mathrm{ab}$ \\
North Fork Shenandoah & 20 & $3.1(1.2) \mathrm{ab}$ & $273.9(39.8) \mathrm{ab}$ & $272.1(141.5) \mathrm{b}$ & $1.21(0.09) \mathrm{ab}$ \\
Conococheague & 16 & $2.3(0.6) \mathrm{b}$ & $222.5(35.4) \mathrm{a}$ & $153.4(84.1) \mathrm{a}$ & $1.27(0.14) \mathrm{b}$ \\
\hline
\end{tabular}

Data are presented as means (standard deviation). Values within a column denoted with the same letter are not significantly different. If no statistical differences were identified among sites for a given parameter, annotation was omitted to facilitate readability. The threshold for statistical significance was $p \leq 0.05$

$N D$ no data 
Table 6 Reproductive parameters of smallmouth bass $M$. dolomieu collected at selected sites in the Potomac drainage and the Gauley River in 2007

\begin{tabular}{|c|c|c|c|c|c|c|}
\hline Site & Sex & Sample size & $\mathrm{GSI}^{\mathrm{a}}$ & Intersex severity & Plasma vitellogenin ${ }^{\mathrm{b}} \mathrm{mg} / \mathrm{ml}$ & $\mathrm{E} / \mathrm{T}$ ratio \\
\hline \multirow[t]{2}{*}{ Gauley } & $\mathrm{F}$ & 9 & $3.21(1.64) \mathrm{a}$ & \multirow[t]{2}{*}{$0.03(0.07) \mathrm{A}$} & $8.366(5.785)$ & $0.87(0.23)$ \\
\hline & M & 8 & $0.49(0.09) \mathrm{A}$ & & $0.024(0.011)$ & $0.12(0.05)$ \\
\hline \multirow[t]{2}{*}{ South Branch Petersburg } & $\mathrm{F}$ & 7 & $6.26(1.17) \mathrm{ab}$ & \multirow[t]{2}{*}{$1.20(0.88) \mathrm{AB}$} & $6.683(1.906)$ & $0.84(0.25)$ \\
\hline & M & 11 & $0.76(0.28) \mathrm{AB}$ & & $0.208(0.180)$ & $0.14(0.06)$ \\
\hline \multirow[t]{2}{*}{ South Branch Springfield } & $\mathrm{F}$ & 5 & $7.20(1.21) \mathrm{b}$ & \multirow[t]{2}{*}{$0.63(0.61) \mathrm{A}$} & $7.897(6.295)$ & $0.92(0.24)$ \\
\hline & M & 14 & $0.57(0.30) \mathrm{AB}$ & & $0.319(0.256)$ & $0.13(0.11)$ \\
\hline \multirow[t]{2}{*}{ Shenandoah South Fork } & $\mathrm{F}$ & 9 & $3.80(1.41) \mathrm{ab}$ & \multirow[t]{2}{*}{$2.10(0.58) \mathrm{B}$} & $3.607(2.779)$ & $0.94(0.42)$ \\
\hline & M & 11 & $0.52(0.08) \mathrm{A}$ & & $0.006(0.006)$ & $0.26(0.24)$ \\
\hline \multirow[t]{2}{*}{ Shenandoah North Fork } & $\mathrm{F}$ & 8 & 3.04 (1.51)ab & \multirow[t]{2}{*}{$1.62(0.72) \mathrm{B}$} & $3.468(1.886)$ & $1.07(0.31)$ \\
\hline & $\mathrm{M}$ & 12 & $0.43(0.11) \mathrm{A}$ & & $0.019(0.016)$ & $0.20(0.11)$ \\
\hline \multirow[t]{2}{*}{ Conococheague Creek } & $\mathrm{F}$ & 8 & $1.81(2.36) \mathrm{a}$ & \multirow[t]{2}{*}{$1.10(0.80) \mathrm{AB}$} & $7.482(6.499)$ & $0.77(0.31)$ \\
\hline & M & 8 & 1.07 (1.49)B & & $\mathrm{BD}$ & $0.30(0.43)$ \\
\hline
\end{tabular}

Data are presented as means and (standard deviation). Values within a column followed by the same letter (lowercase for females, uppercase for males) are not significantly different at $p \leq 0.05$

$E / T$ ratio estrogen/testosterone ratio, $B D$ below detection, GSI gonadosomatic index

${ }^{\text {a }}$ Gonadosomatic index calculated as (gonad weight/body weight) $\times 100$

${ }^{\mathrm{b}}$ Mean and (standard deviation) of only those with measurable vitellogenin

0.8 as a lower threshold for normal females (Baldigo et al. 2006). In this study, the mean $E / T$ ratio for female SMB ranged from a high of 1.07 in those collected from the North Fork Shenandoah to a low of 0.77 in SMB from the Conococheague. The male mean $\mathrm{E} / \mathrm{T}$ ratio ranged from a high of 0.30 in $\mathrm{SMB}$ from the Conococheague to a low of 0.12 in those from the Gauley (Table 6). While there were no significant differences among site $\mathrm{E} / \mathrm{T}$ means for either male $(p=0.09)$ or female $(p=0.34) \mathrm{SMB}$, there were individual fish which had ratios outside of the conservative normal range. Only one male from Conococheague Creek had a ratio of 1.32 , while all others were below 1.0. However, there were numerous female SMB with E/T ratios less than 0.8. The percent of female SMB below the normal threshold were as follows: North Fork Shenandoah 12.5\%, Gauley 22\%, South Branch Springfield 40\%, South Branch Petersburg 43\%, South Fork Shenandoah $44 \%$, and Conococheague $63 \%$.

Seasonal and annual comparisons of TO, plasma vitellogenin, and reproductive hormones

At three sites within the Shenandoah River drainage, the South Fork, North Fork, and a site on the mainstem (Fig. 1), SMB were collected in March, July, and October 2006 and March 2007. The sex ratio did vary from site to site and season to season; however, small sample sizes precluded any meaningful interpretation of the sex ratios. Age varied among the sites only in October (Table 7).

The mean concentration of plasma Vtg in female SMB at all sites declined to very low levels in July 2006, began to increase by October 2006, and showed a continued increase through the March 2007 sample. While the concentrations at the three sites were very similar in March 2007, there were differences among the sites in March 2006, with females from the North Fork having lower plasma Vtg concentrations (Fig. 6a). Interestingly, although there were no significant differences in the mean concentrations of Vtg in female SMB from the three sites in July 2006, there was a difference in the percent of females showing measurable amounts. Less than $40 \%$ of the female SMB collected at both the mainstem and South Fork sites had measurable concentrations of Vtg in July 2006 versus 100\% of those collected at the North Fork site (Fig. 6b). During this sampling period, GSI of females were not significantly different with means and standard deviations ranging from $0.51 \pm 0.37$ in the North Fork to $0.35 \pm 0.27$ in the 

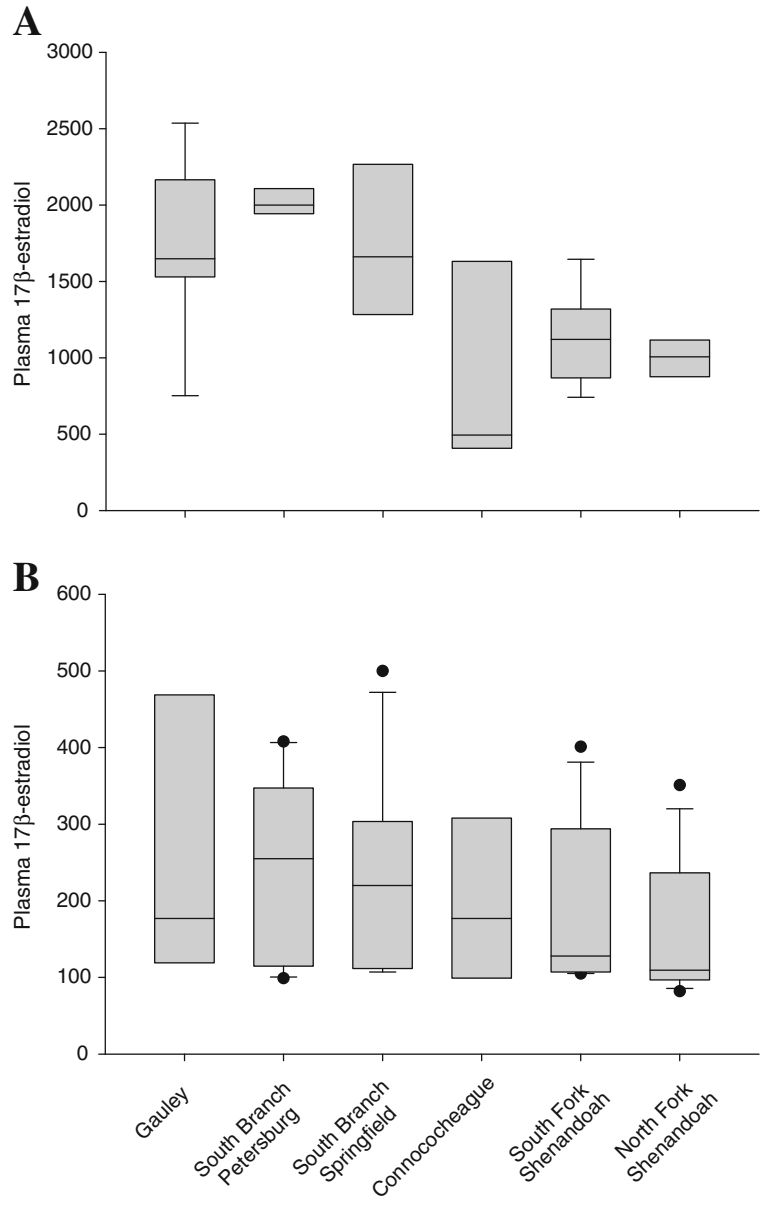

Fig. 4 Plasma concentrations of estradiol in smallmouth bass collected in the Gauley and Potomac River drainage in 2007. a Female, b male. The box represents the 25-75 percentile, the whiskers the 10th and 90th percentiles, the horizontal line within the box is the median, and outliers are indicated by dots

South Fork and $0.39 \pm 0.18$ in the mainstem. There was also no difference in the ovarian maturity stage with all groups having primarily stage 1 oocytes (data not shown).

The percentage of male SMB with Vtg in July 2006 was also high $(>80 \%)$ in those from the North Fork, while less than $40 \%$ of males from the mainstem and South Fork had detectable amounts. The same seasonal trends for percentage of male SMB with Vtg were observed at all sites with the highest percentage noted in July (Fig. 7a). The percentage of male SMB with TO varied seasonally at both the North and South Fork sites. In these samples, the prevalence decreased in July 2006 but increased again by October. The prevalence of TO in
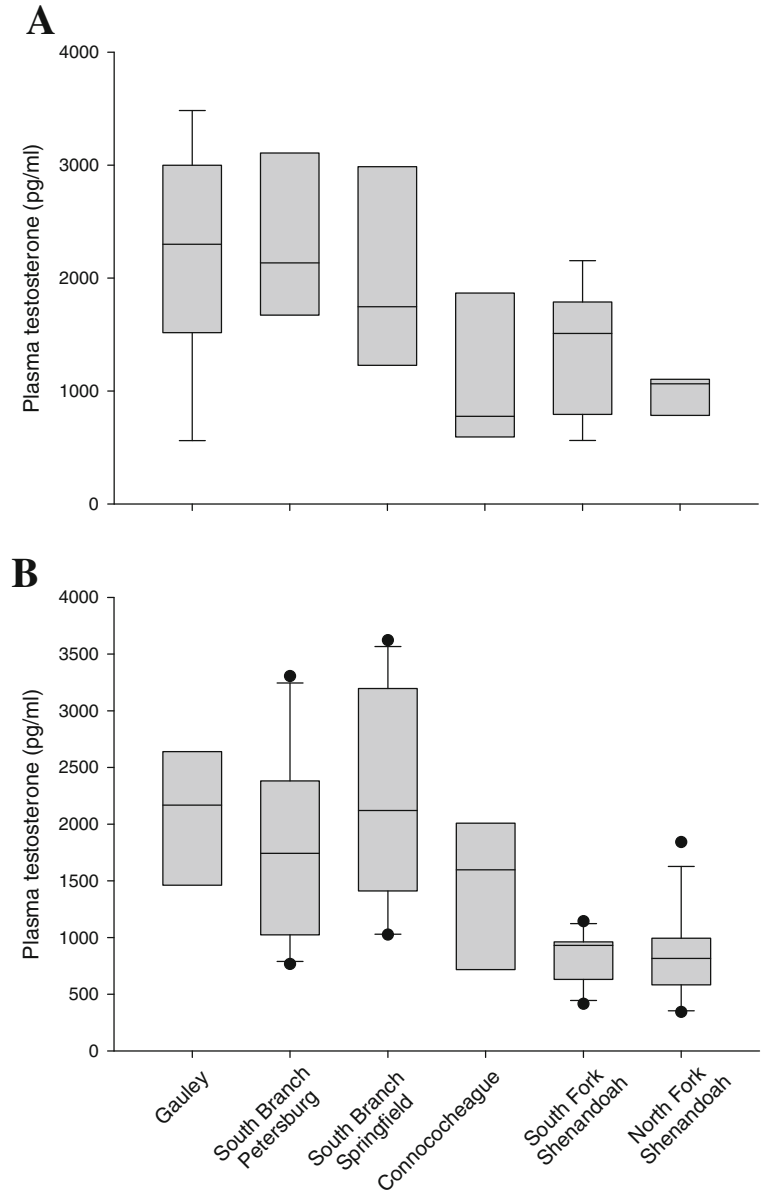

Fig. 5 Plasma concentrations of testosterone in smallmouth bass collected in the Gauley and Potomac drainage in 2007. a Female, b male. The box represents the 25-75 percentile, the whiskers the 10th and 90th percentiles, the horizontal line within the box is the median, and outliers are indicated by dots

SMB collected from the mainstem site was similar throughout the year (Fig. 7b). During microscopic evaluation of testes collected during the spring samplings, it is not unusual to observe immature oocytes among spermatozoa within the lumen of tubules (Fig. 2b). However, there were also differences among sites in the histologic appearance of the testicular tissue during the summer. All of the male SMB collected at the North Fork and all but one collected at the South Fork had stage 1 testicular tissue and residual sperm were noted in the tubules (Fig. 2c). Conversely, only three of the nine male SMB collected at the mainstem site had residual sperm (Fig. 2d), suggesting the other six were immature fish that had not spawned the previous 
Table 7 Seasonal sample sizes and ages of smallmouth bass $M$. dolomieu collected at three sites in the Shenandoah River

Data are presented as mean and (standard deviation). Values within a block representing sampling time and site followed by the same letter or no letters are not significantly different at $p \leq 0.05$

$N D$ no data

\begin{tabular}{|c|c|c|c|c|c|}
\hline \multirow[t]{2}{*}{ Season } & \multirow[t]{2}{*}{ Site } & \multicolumn{2}{|c|}{ Female smallmouth bass } & \multicolumn{2}{|c|}{ Male smallmouth bass } \\
\hline & & Sample size & Age & Sample size & Age \\
\hline \multirow[t]{3}{*}{ March 2006} & Mainstem & 6 & $2.5(1.0)$ & 14 & $2.5(1.1)$ \\
\hline & South Fork & 7 & ND & 13 & ND \\
\hline & North Fork & 10 & $3.0(0.9)$ & 10 & $2.7(1.2)$ \\
\hline \multirow[t]{3}{*}{ July 2006} & Mainstem & 9 & $2.9(2.4)$ & 9 & $2.0(0.5)$ \\
\hline & South Fork & 11 & $2.3(0.9)$ & 9 & $2.8(2.1)$ \\
\hline & North Fork & 12 & $2.7(0.9)$ & 8 & $2.0(0.0)$ \\
\hline \multirow[t]{3}{*}{ October 2006} & Mainstem & 6 & $1.9(0.4)$ & 10 & $1.6(0.5)^{\mathrm{a}}$ \\
\hline & South Fork & 10 & $2.3(0.7)$ & 10 & $2.3(0.9)^{\mathrm{a}, \mathrm{b}}$ \\
\hline & North Fork & 8 & $2.8(0.9)$ & 12 & $2.7(1.0)^{\mathrm{b}}$ \\
\hline \multirow[t]{3}{*}{ March 2007} & Mainstem & 10 & $3.2(1.0)$ & 5 & $3.6(1.3)$ \\
\hline & South Fork & 9 & $3.6(0.9)$ & 11 & $3.7(1.1)$ \\
\hline & North Fork & 8 & $3.1(1.0)$ & 12 & $3.1(1.3)$ \\
\hline
\end{tabular}

spring. The GSI of male SMB from the mainstem site was significantly less $(0.08 \pm 0.05)$ than that at the North Fork $(0.44 \pm 0.27)$ and less, although not significantly, than that at the South Fork $(0.29 \pm$ 0.26 ), also suggesting sexually immature individuals.
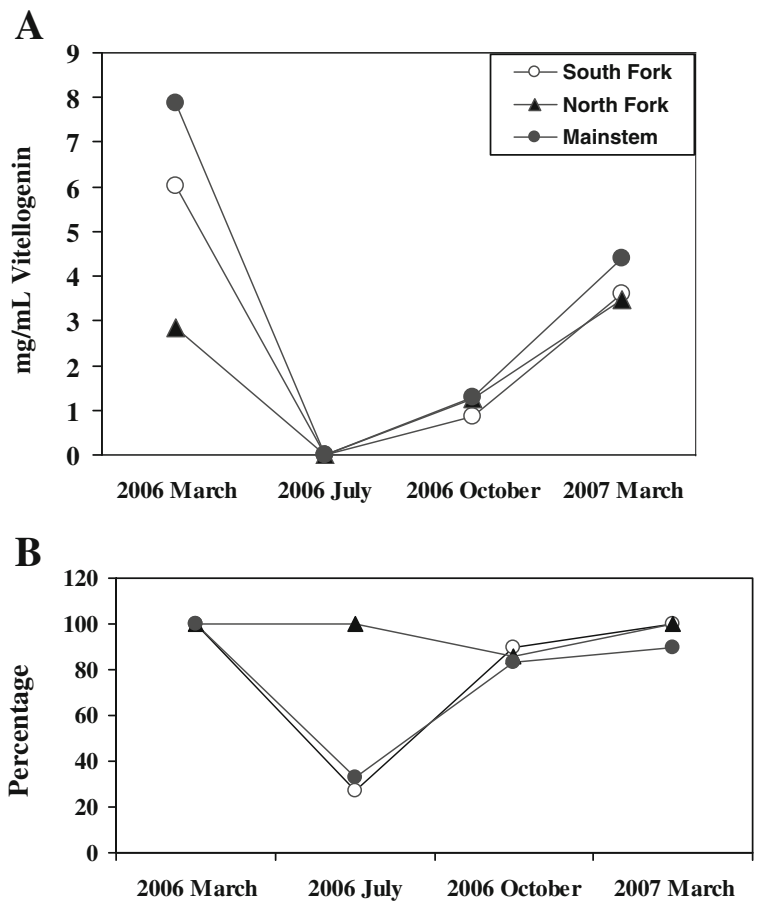

Fig. 6 Seasonal trends of plasma vitellogenin in female smallmouth bass $M$. dolomieu. a Mean plasma vitellogenin concentrations (milligrams per milliliter). b Percentage of female bass with measurable vitellogenin concentrations
The trends in prevalence of TO during the spring were similar between 2006 and 2007, with the bass collected in the Gauley River having the lowest

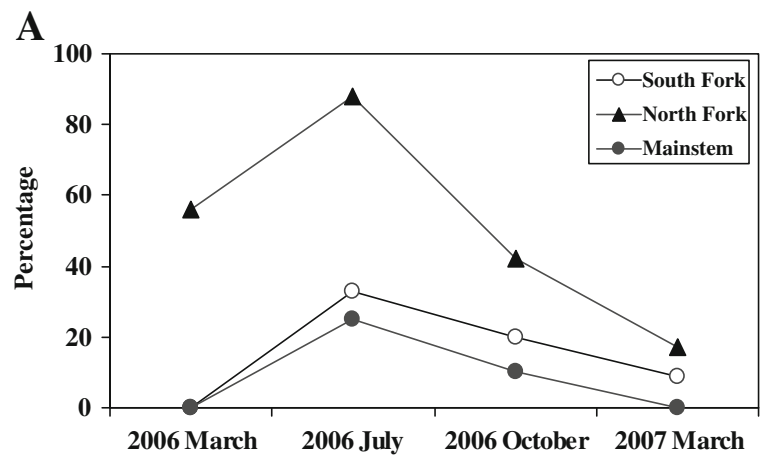

B

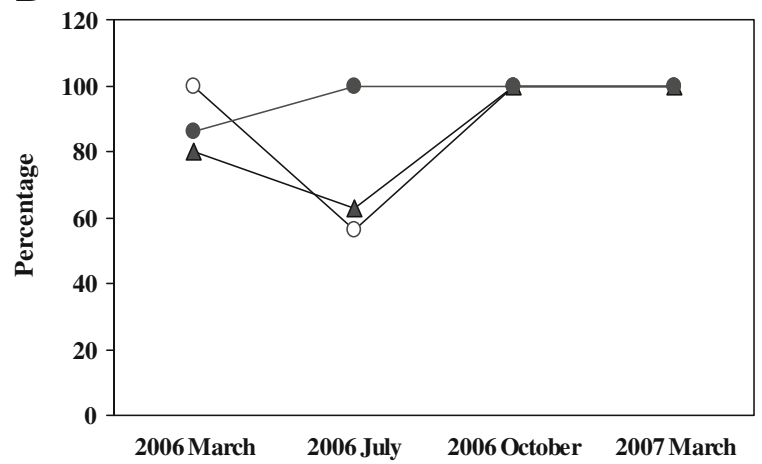

Fig. 7 Seasonal trends of reproductive endocrine biomarkers in male smallmouth bass collected at three sites within the Shenandoah drainage. a Percentage of males with measurable plasma vitellogenin. b Percentage of males with testicular oocytes 
prevalence, those from the South Branch generally moderate to high, and those from the Shenandoah sites the highest (Fig. 3). There was no correlation between TO and Vtg in male bass.

Seasonal trends in reproductive hormones were noted at all three sites on the Shenandoah. Concentrations were similar at all sites in July and October, but there was variation among the sites in the spring, particularly for female estradiol in March 2006, male estradiol in March 2007 (Fig. 8), and female testosterone concentrations in both years (Fig. 9).

Relative estrogenicity of POCIS extracts

Polar organic chemical integrative samplers were deployed for periods ranging from 28 to 35 days in spring 2007 at the Gauley, South Branch Petersburg, South Fork Shenandoah, and Conococheague Creek sites. Estimated estradiol equivalents as assessed
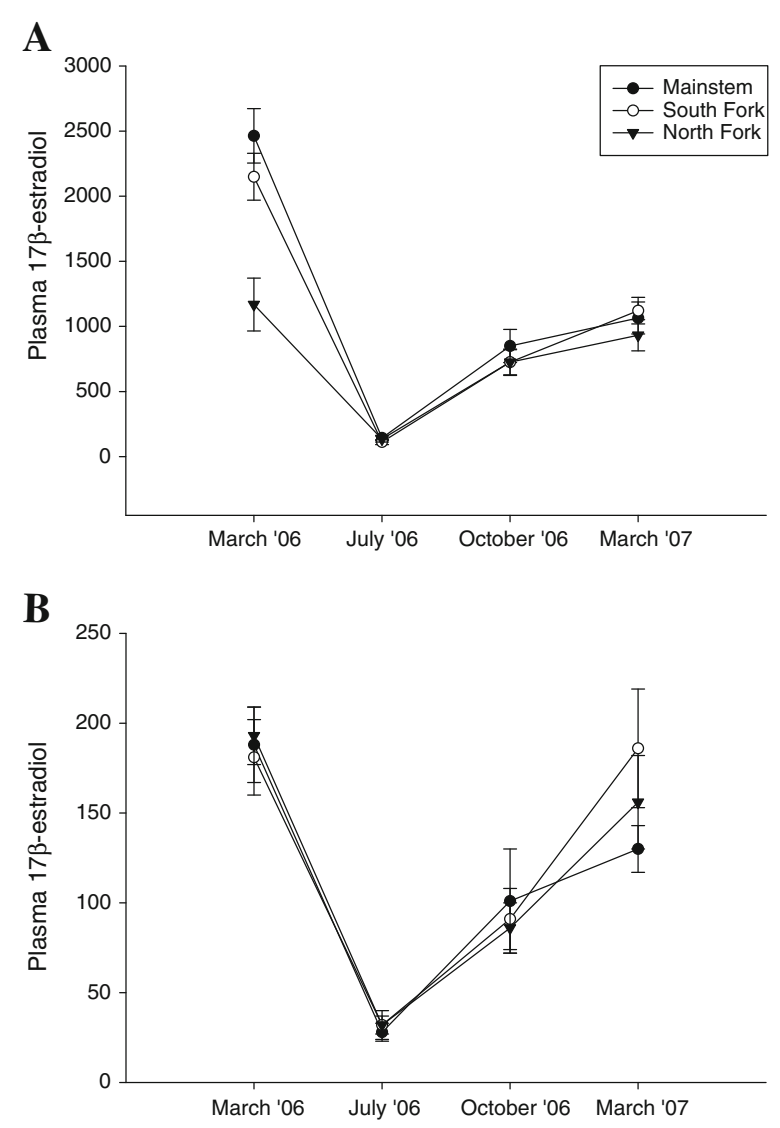

Fig. 8 Seasonal and site comparisons of plasma $17 \beta$ estradiol in smallmouth bass collected at three sites in the Shenandoah drainage. a Female smallmouth bass. b Male smallmouth bass
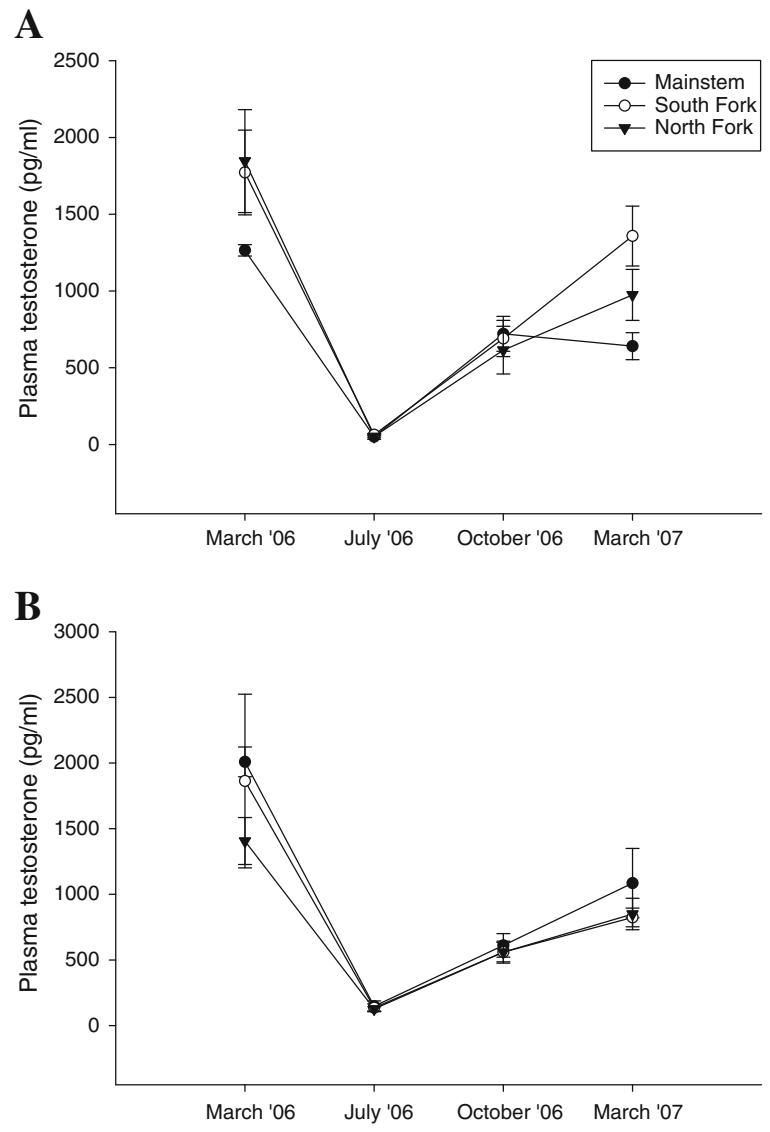

Fig. 9 Site and seasonal comparison of plasma testosterone in smallmouth bass collected at three sites in the Shenandoah River drainage. a Female smallmouth bass. b Male smallmouth bass

using the YES and BLYES assays ranged from nondetectable at the Gauley to $9.1 \mathrm{ng} / \mathrm{l}$ estradiol equivalents/sample at the Conococheague (Table 8). Results of the YES and BLYES assays corresponded well.

Land-use and testicular oocyte prevalence and severity

A variety of land-use characteristics and point source evaluations of the sites indicated a range in human population densities from a low of 0.06 people/ha in the Gauley catchment to 0.69 people/ha in the Conococheague Creek catchment. Similarly the percent of agricultural land use in the catchment ranged from a low of $0.5 \%$ in the Gauley River catchment to $50.3 \%$ in the Conococheague Creek catchment. The highest number of WWTP and the highest number 
of animal feeding operations were found in the Shenandoah River catchments (Table 9).

Correlation analysis of land-use characteristics and intersex indicated an association of intersex severity with WWTP flow $\left(r^{2}=0.63, p=0.02\right)$, percent of agricultural land use $\left(r^{2}=0.50, p=0.05\right)$, the number of AFO $\left(r^{2}=0.56, p=0.03\right)$, the number of poultry houses $\left(r^{2}=0.50, p=0.05\right)$, and animal density $\left(r^{2}=\right.$ $0.58 ; p=0.03)$. Only the percent of agricultural land use $\left(r^{2}=0.63, p=0.02\right)$ and animal density within the catchment $\left(r^{2}=0.49, p=0.05\right)$ were associated with intersex prevalence (Table 10).

\section{Discussion}

Many factors influence the responses to, and consequently effects of, exposure to the complex chemical mixtures that wild aquatic populations encounter. Certainly one of these is species differences. Differences have been demonstrated in the responses (both presence or absence and magnitude) of wild fish species collected in the same locations in field monitoring or assessment studies (Kavanagh et al. 2004; Vine et al. 2005; Baldigo et al. 2006; Hinck et al. 2009) and among species in more controlled laboratory or experimental pond exposures (Routledge et al. 1998; Thompson et al. 2000; Van den Belt et al. 2003; Palace et al. 2009; Yonkos et al. 2010). Smallmouth bass, like roach Rutilus rutilis studied extensively in Europe (Jobling et al. 1998; Nolan et al. 2001; Tyler et al. 2007), appears to be a sensitive and potentially important sentinel species for reproductive endocrine disruption studies. Hence, it is necessary to understand the normal variation and temporal changes that may occur naturally, as well as those induced by chemical exposure. Both TO and Vtg are widely used biomarkers of reproductive endocrine disruption and exposure to chemicals of emerging concern, but may be induced by different physiological mechanisms, chemical types, lengths, and timing of exposure. Typically, Vtg is detected only in significant concentrations in mature adult females, yet exposure to estrogenic compounds can induce measurable levels in immature and male fishes. Therefore, Vtg concentrations are used in various screening and testing protocols (Ankley et al. 1998; Wheeler et al. 2005; Hutchinson et al. 2006) and in monitoring and assessment studies 
Table 9 Comparison of potential sources of chemical contaminants in study catchments within the Potomac river drainage and the Gauley River

\begin{tabular}{|c|c|c|c|c|c|c|c|c|}
\hline Site & $\begin{array}{l}\text { Human } \\
\text { density }^{\mathrm{a}}\end{array}$ & WWTPno. ${ }^{\mathrm{b}}$ & $\begin{array}{l}\text { WWTP } \\
\text { flow }^{c}\end{array}$ & $\% \mathrm{Ag}^{\mathrm{d}}$ & $\mathrm{AFO}^{\mathrm{e}}$ & $\begin{array}{l}\text { Animal } \\
\text { numbers }\end{array}$ & $\begin{array}{l}\text { Animal } \\
\text { density }^{\mathrm{g}}\end{array}$ & Intersex $^{h}$ \\
\hline Gauley River & 0.06 & 0 & 0 & 0.5 & 0 & 464 & 0.03 & $\begin{array}{l}11.3 \% \\
0.02(0.07)\end{array}$ \\
\hline South Branch Petersburg & 0.07 & 3 & 0.95 & 16.4 & $296(296)$ & $1,450,120$ & 6.59 & $\begin{array}{l}74.3 \% \\
0.97(0.95)\end{array}$ \\
\hline South Branch Moorefield & 0.07 & 4 & 1.43 & 15.2 & $497(496)$ & $7,384,685$ & 23.44 & $\begin{array}{l}54.5 \% \\
0.50(0.50)\end{array}$ \\
\hline South Branch Springfield & 0.08 & 5 & 1.93 & 15.2 & $565(562)$ & $8,719,093$ & 22.82 & $\begin{array}{l}82.2 \% \\
1.02(0.76)\end{array}$ \\
\hline Shenandoah North Fork & 0.28 & 50 & 1.59 & 32.7 & $1,174(960)$ & $11,757,596$ & 48.79 & $\begin{array}{l}90.0 \% \\
1.16(0.78)\end{array}$ \\
\hline Shenandoah South Fork & 0.56 & 19 & 20.84 & 35.9 & $2,029(1,176)$ & $14,788,173$ & 46.21 & $\begin{array}{l}100.0 \% \\
\quad 1.83(0.65)\end{array}$ \\
\hline Shenandoah Mainstem & 0.43 & 101 & 25.66 & 32.6 & $3,655(2,539)$ & $33,928,442$ & 43.94 & $\begin{array}{l}93.0 \% \\
1.64(0.93)\end{array}$ \\
\hline Conococheague Creek (lower) & 0.69 & 13 & 8.31 & 50.3 & $10(1)$ & $1,819,225$ & 12.51 & $\begin{array}{l}87.5 \% \\
1.03(0.78)\end{array}$ \\
\hline
\end{tabular}

${ }^{a}$ Human population/catchment area or number of people/hectare (from Table 1)

${ }^{\mathrm{b}}$ Number of permitted sewage system dischargers in catchment, from EPA's permit compliance system

${ }^{\mathrm{c}}$ Permitted average flow rate (million gallons per day) from sewage dischargers in catchment

${ }^{\mathrm{d}}$ Percent agriculture from Table 1

${ }^{\mathrm{e}}$ Animal Feeding Operations including poultry (from USGS Leetown Science Center Aquatic Ecology Branch Google Earth/air photo mapping originally map in 2009, updated in 2010), dairy, beef, swine, and others (Shenandoah sites from the State of Virginia, DCR, all others from Google Earth mapping). Numbers in parentheses are poultry houses

${ }^{\mathrm{f}}$ Numbers of animals including poultry (except broilers sold), cattle, sheep, and swine reported by county in the Agricultural Census of 2007, adjusted by area of county in catchment draining sample site

${ }^{g}$ Total number of animals/catchment area in hectares (from Table 1)

${ }^{\mathrm{h}}$ Intersex prevalence (percent) with severity below presented as mean and (standard deviation) of data from spring 2006 and 2007 combined, if available

Table 10 Correlation (Pearson) analysis of intersex prevalence or severity and land-use characteristics within the catchment

Values in bold are considered significant WWTP wastewater treatment plant

\begin{tabular}{|c|c|c|c|c|}
\hline \multirow[t]{2}{*}{ Land-use characteristics } & \multicolumn{2}{|c|}{ Intersex prevalence } & \multicolumn{2}{|c|}{ Intersex severity } \\
\hline & $r^{2}$ & $p$ & $r^{2}$ & $p$ \\
\hline Human population density & 0.39 & 0.10 & 0.42 & 0.08 \\
\hline Number of WWTP & 0.22 & 0.24 & 0.34 & 0.13 \\
\hline WWTP flow & 0.32 & 0.15 & 0.63 & 0.02 \\
\hline Percent agriculture & 0.63 & 0.02 & 0.50 & 0.05 \\
\hline Total animal feeding operations & 0.28 & 0.17 & 0.56 & 0.03 \\
\hline Poultry houses & 0.27 & 0.18 & 0.50 & 0.05 \\
\hline Total animal numbers & 0.27 & 0.18 & 0.48 & 0.06 \\
\hline Animal density & 0.49 & 0.05 & 0.58 & 0.03 \\
\hline
\end{tabular}


(Tyler et al. 1999; Schmitt and Dethloff 2000; van Aerle et al. 2001). Induction of Vtg is a dynamic process regulated by both synthesis and elimination rates and may be representative of relatively recent exposures of juvenile or adult male fishes. Vitellogenin concentrations in female fishes may also be affected by exposure to EDC, and a downregulation of Vtg in mature female fishes can be indicative of anti-estrogenic activity (Smeets et al. 1999; Panter et al. 2000).

Testicular oocytes have been induced experimentally in numerous fish species by exposure to estrogens and other chemicals (reviewed by Dietrich and Krieger 2009). However, the presence of TO, even in adult males, may be more indicative of early life stage exposure, as opposed to induction of Vtg in males or immature fish. Larval stages have been shown to be the most sensitive period of exposure for induction of TO in a number of fish species (Gray et al. 1999; Koger et al. 2000; Krisfalusi and Nagler 2000; Metcalfe et al. 2000; Liney et al. 2005). However, there are two windows of enhanced sensitivity to EDC - the larval or yolk sac stage when gonad differentiation occurs and the reproduction period or gonadal recrudescence (seasonal maturation) in mature adults (Ankley and Johnson 2004). Seasonal maturation is an activational (rather than organizational) event (Yamamoto 1969; Monosson et al. 1997). However, exposures during the "critical window" of sexual differentiation, when organizational processes are taking place, may also result in adverse effects manifested later in the life cycle (Yamamoto 1969; Monosson et al. 1997; Bigsby et al. 1999). Hence, transient exposure to contaminants during early developmental stages may induce organizational effects that are manifested once the organism reaches sexual maturity (Guillette et al. 1996; Metcalfe et al. 2000). This could be due to increased numbers of estrogen receptors, enhanced affinity for the receptors, or modulation of the transcriptional signals. Consequently, fish exposed during early life stages may be more sensitive to exposure and TO induction later in life (Liney et al. 2005).

Black bass (smallmouth and largemouth Micropterus salmoides) begin to undergo recrudescence in the fall and spawn in spring. During this time, numerous physiological changes occur. The gonad weight and hence GSI begins to increase due to gamete proliferation and maturation, peaking imme- diately prior to release of eggs and sperm. Androgen and estrogen levels increase with spermatogenesis, vitellogenesis, and oocyte maturation. In females, plasma Vtg concentrations decrease to baseline after spawning (i.e., summer) and then increase from fall through spring spawning (Rosenblum et al. 1994; Gross et al. 2002; Yambe et al. 2004). Theoretically, $\mathrm{Vtg}$ induction in males and immature individuals, or females at times of the year when levels should be baseline, would be indicative of exposure to chemicals interacting with the estrogen receptors in the liver. However, the magnitude and duration of response depends on many factors including species, sex, water temperature, and chemical concentration. In male rainbow trout Oncorhynchus mykiss dosed with ethinylestradiol $\left(\mathrm{EE}_{2}\right)$ via intra-arterial injection, circulating Vtg was observed at approximately $12 \mathrm{~h}$ post-injection, peaked around 7-9 days irrespective of dose, and dropped to near base levels by 48 days. The levels of $\mathrm{EE}_{2}$ used were relatively high, 0.001 to $10 \mathrm{mg} / \mathrm{kg}$. Elimination was also not significantly affected by dose except at the highest dose (Schultz et al. 2001). Sheepshead minnows Cyprinodon variegates exposed via water to 0.1 or $1.0 \mu \mathrm{g} / \mathrm{l}$ estradiol for 16 days and then kept in clean water showed a peak in plasma Vtg at 2-4 days after the exposure period ended. The higher dose did induce higher plasma concentrations; however, elimination rate did not appear to be dose-related. Both groups returned to basal levels at approximately 112 days (Hemmer et al. 2002). Yonkos et al. (2010) found that only 50\% of male fathead minnows had elevated plasma Vtg levels after a 9-day exposure to poultry litter-derived estrogenicity, while $100 \%$ had significantly elevated levels after 21 days. Higher concentrations of estrogenic chemicals or exposure over an extended period may result in accumulations of Vtg that take months to reach undetectable levels.

The percentage of female SMB collected in the North Fork Shenandoah with detectable plasma Vtg remained high throughout the year, while in SMB from both the mainstem and South Fork sites the percentage with measurable Vtg dropped in July, as would be expected for a normal physiological cycle (Rosenblum et al. 1994; Gross et al. 2002; Yambe et al. 2004). Interestingly, the highest percentage of males with measurable Vtg was also collected in the North Fork Shenandoah and peaked between March and July (Fig. 7a). This may indicate the most 
significant exposure occurred between March and July and that exposures in the North Fork were of higher concentrations or longer, more continual duration than at the other two sites. Temporal studies of total estrogenicity and chemical concentrations are needed to better understand these observations.

The prevalence of male SMB with TO decreased during the summer, after spring spawning in both the North and South Fork Shenandoah. Similar observations were made with the estuarine blenny Zoarces viviparous from the Tyne estuary, England. Twentyfive percent of the male blenny captured in the spring were intersex while none of those collected in the fall was intersex. It was suggested this was due to shedding of the oocytes with sperm during spring spawning, a reabsorption of oocytes or sampling from a different population (Stentiford et al. 2003). The observation of oocytes in the lumen of the SMB tubules (Fig. 2b) provided some evidence that shedding of oocytes during spawning may be one factor responsible for the seasonal differences. If so, then summer sampling of bass which had not spawned the previous spring could result in a higher TO prevalence then if they had spawned. No seasonal difference in the prevalence of TO was observed in SMB collected from the mainstem site, where more immature individuals that appeared not to have spawned the previous spring were collected. An alternative explanation for higher TO prevalence in the spring and fall is land-use practices such as the application of manure and pesticides to agricultural fields and increased runoff during these times.

It is currently unknown whether the TO prevalence and severity observed in bass from the Potomac is a consequence of early life stage exposure, long-term exposure of adults, or a combination of both. Both site and seasonal differences may relate to timing and concentrations of EDC exposure in these populations. Even in controlled laboratory experiments, responses to exposures of individual chemicals or chemical mixtures were influenced by timing of exposure (Hyndman et al. 2010) and whether exposure was intermittent or constant (Panter et al. 2000). If exposure during early life stages is a primary factor than climatic conditions such as rainfall may play a significant role in the TO prevalence in different year classes. Increased rainfall may lead to increased runoff of animal wastes, pesticides, and other EDCs associated with agricultural and other nonpoint sources. Conversely, in the vicinity of WWTP, increased flow may have a dilution effect. Larger datasets from multiple sites are necessary to examine the influence of age, year class, and duration of exposure on TO prevalence and severity.

Data from parallel studies in which POCIS samplers were deployed at sites throughout the Shenandoah in spring 2007 further highlight the complexities of understanding exposure scenarios in wild fishes. In one study, samplers were deployed at two sites on the North Fork during two time periods, March 10, 2007-April 29, 2007 and April 29, 2007June 9, 2007. Extracts from replicates at these sites were used to determine estimated estradiol equivalents (EEQ) using the YES assay. During the first time period at one site, 22 and 55 EEQ (ng E2/sample) were measured and 21 and 79 EEQ during the second time period. At the second site, EEQ were 14 and 55 during the first time period and 55 and 61 during the second (Alvarez et al. 2008a). The second study also included three sites on the North Fork as well as three on the South Fork. These samplers were deployed from late March to early May. North Fork sites ranged from 2.4 to $12 \mathrm{EEQ} /$ sampler extract and at the South Fork from 5.5 to 11 (Alvarez et al. 2008b). These studies demonstrate the variability that may be observed even at sites located in the same rivers. Unfortunately, analyses for EDC and other chemicals of emerging concern in the Shenandoah have only been conducted in the spring so the seasonal variability is not known. These data illustrate the need for concurrent biological and chemical analyses conducted spatially and temporally.

Another objective of this study was to examine other reproductive endpoints in conjunction with the presence/severity of TO. Relationships among biomarkers such as TO or Vtg in males and the health of individual animals or populations is not clear for SMB or most other fish species. We compared Vtg concentrations and sperm characteristics of male SMB collected from three sites within the South Branch Potomac, where a moderate to high prevalence of TO was observed, to those collected in the Gauley, a reference site. No male SMB collected at the Gauley had detectable Vtg, although one male did have TO. Within the South Branch, interestingly, there was no detectable Vtg noted in males at the site (Springfield) with the highest prevalence of TO. The range of TO prevalence at sites within the South 
Branch was $54.5 \%$ to $100 \%$ (Table 3). Bass from the Gauley also had a higher sperm count and more motile sperm than those collected from bass in the South Branch (Table 4), although no significant difference in GSI were found (Table 3). An inverse relationship was found between intersex and motility. These findings are similar to those observed in intersex roach which had lower quality sperm (reduced fertilizing capacity) compared to reference males (Jobling et al. 2002). Bass from the Gauley river were smaller than those collected in the Potomac drainage in 2006 (Table 2). Anecdotal information suggests a much slower growth rate for SMB in the Gauley drainage than in the Potomac. Unfortunately, this led to difficulty in aging the otoliths, and reliable age data were not obtained. However, all bass from the Gauley were sexually mature and so we believe the potential age differences are unlikely to explain the differences in sperm quantity and motility. However, further studies are required to address the effects of age/year class/size on these biological endpoints in SMB.

It is not clear whether the observed effects on sperm characteristics could have a population effect over time. Select studies have demonstrated population effects of exposure to estrogenic compounds; however, most were conducted on small, relatively short-lived species such as zebrafish Danio rerio (Nash et al. 2004) or fathead minnows Pimephales promelas (Kidd et al. 2007). Bass have a much longer life span than these species. Individuals collected in 2006 from the South Branch ranged in age from 2 to 8 , and individuals as old as age 10 were collected in 2007. Hence, if population effects do occur, it may take many years to manifest. Recent studies with roach, a longer-lived species, demonstrated that reproductive performance (proportion of offspring sired by an individual) was reduced in severely intersex males. However, it was concluded that implications to fish populations were likely only if a high proportion of severe intersex (severity $\geq 4$ ) males were present (Harris et al. 2010). Only a few of our sites had a high proportion of moderately (intersex index $>2$ ) intersex males.

While it is currently not known if the magnitude of TO and lower sperm quantity and quality could eventually lead to population effects in bass, it is important to recognize that population effects of EDCs can occur by pathways other than the reproductive effects. For the fathead minnow study in the Experi- mental Lakes, it is not known whether the population crash was due strictly to reproductive failure or an increased mortality rate of the adults due to the other pathological effects (Palace et al. 2002; Kidd et al. 2007). Health effects, including immunomodulation and genotoxicity, have been reported downstream of WWTP in fathead minnows (Filby et al. 2007) and roach (Liney et al. 2006). It is interesting to note that spring mortalities of the mature adult SMB have occurred in the same areas as those with a high prevalence of TO and have caused reductions in adult populations (Blazer et al. 2010). The occurrence of intersex in male bass may be an early indicator of exposure to potentially damaging chemicals which affect individuals and populations through numerous physiological changes including reduction in reproductive capacity and increased infectious disease/parasite susceptibility. Hence, the cumulative impacts of cooccurring stressors need to be addressed to fully understand and predict effects of EDC exposure to both the individual and the population.

Multiple lines of evidence were employed to better understand the sources of EDC in the Potomac drainage, including POCIS deployment and consequent testing of the extracts for EEQ as well as land-use mapping and analysis. One complexity is the low concentrations at which these chemicals may cause effects. Another is the inherent issue of complex mixtures and potential additivity, synergism, or antagonism of responses to chemicals within the mixture. Temporal variability in estrogenicity has also been demonstrated with individual sources such as WWTP (Rodgers-Gray et al. 2000; Hemming et al. 2004; Martinović et al. 2008) and agricultural runoff/atmospheric deposition (Hamers et al. 2003; Kolodziej et al. 2004; Lavado et al. 2009). A grab sample of water offers a snapshot of water quality and often does not allow for the measurement of chemicals at concentrations known to cause adverse effects. For instance, studies on 26 species resulted in the predicted no-effect concentration of the synthetic estrogen $17 \alpha$-ethinylestradiol in surface waters to be $0.35 \mathrm{ng} / \mathrm{l}$ (Caldwell et al. 2008). The proposed no observable effect concentration for the natural estrogen $17 \beta$-estradiol is $1 \mathrm{ng} / \mathrm{l}$ (Young et al. 2002). These concentrations are close to or below the method detection (MDL) and quantification (MQL) limits of these hormones (MDL $1.3 \mathrm{ng} / \mathrm{l}$ for $17 \beta$-estradiol and $0.66 \mathrm{ng} / \mathrm{l}$ for $17 \alpha$-ethinylestradiol, Alvarez et al. 2008 b) in many studies. 
To address the low concentration issues, POCIS devices were deployed for weeks to months to theoretically sequester chemicals from the water similar to that of a fish. Because they are deployed for an extended time, they can integrate base flow and any episodic runoff events. However, only dissolved chemicals will be taken up; therefore, chemicals associated with particulates, suspended sediments, or colloidal matter will not be measured, although these forms may be taken up by the fish (Newcombe and MacDonald 1991). In addition, the microenvironment of the deployment site, particularly flow and membrane biofouling, can affect uptake and dissipation. Hence, as indicated above, extracts from samplers deployed in close proximity, such as the replicates reported by Alvarez et al. (2008b), can be significantly different in terms of estrogenicity. Despite these caveats, total estrogenicity, as measured by the BLYES assay, did show a similar trend to that of TO prevalence and severity. Samples from the Gauley River had no detectable estrogenicity and low TO prevalence and severity, the South Branch sites had moderate estrogenic activity and moderate to high TO prevalence and severity, while the South Fork Shenandoah and Conococheague Creek sites had the highest estrogenic activity and highest TO prevalence and severity (Table 8).

Another line of evidence for investigating the sources of EDCs was the association of land use, including point and nonpoint sources of pollution, with TO prevalence and severity. In the areas of the Potomac watershed studied, it was difficult to distinguish the impact from human population density and agricultural intensity as both showed similar trends. The out-of-basin reference site on the Gauley has low human population density and a low percent of agricultural land use. Within the Potomac drainage, Conococheague Creek had the highest human population density and the highest percentage of agricultural land use (Table 9). Correlation analysis, while not providing cause and effect, did provide additional evidence for the importance of certain land-use practices. As previously indicated, WWTPs are a well-established source of estrogenic compounds and there was a significant association between the permitted average WWTP flow rate and TO severity $\left(r^{2}=0.63 ; p=0.02\right)$, but not with TO prevalence.

The occurrence and effects of EDC have previously been documented in agricultural watersheds (Kolodziej et al. 2004; Soto et al. 2004; Matthiessen et al. 2006;
Kolodziej and Sedlak 2007; Lavado et al. 2009). In the catchments studied, associations with TO prevalence were only noted for the percent of agricultural land use and animal density. Intersex severity was significantly associated with a number of agricultural measures including percent of agricultural land use, total number of AFO, number of poultry houses, and animal density (Table 10). The South Branch sites had a human density only slightly higher than the Gauley and moderate agricultural intensity (15-16\%). Interestingly almost all the AFO in the South Branch catchments are poultry (Table 9), and an association was found between the number of poultry houses and TO severity. This is consistent with recent laboratory studies that showed 21-day exposures to environmentally relevant concentrations of poultry litter-associated contaminants induced $\mathrm{Vtg}$ in adult male fathead minnows and exposures of larval minnows resulted in a dosedependent feminization (Yonkos et al. 2010). The Shenandoah has approximately two to ten times the AFO as the South Branch; however, they are a mix of poultry and other livestock, primarily cattle. The Shenandoah sites also had a higher human population density than the South Branch catchments. Conversely, the Conococheague Creek catchment contained fewer AFO than the catchments in the South Branch and Shenandoah, although agricultural land use was the highest (Table 9). Hence, other sources such as pesticides/herbicides from agricultural fields or various contaminants in stormwater runoff may contribute to the induction of TO. Previous studies have shown sitespecific profiles of estrogenic activity in agricultural areas (Lavado et al. 2009) and that, while basin-wide impacts to fish populations may be demonstrated (Jeffries et al. 2008, 2010), the importance of various sources may differ from site to site (Jeffries et al. 2008). Our data would suggest this is true in the Potomac basin as well.

Estrogens and estrogenic compounds have been the most studied chemicals in terms of induction of TO. However, other chemicals which act by mechanisms other than the estrogen receptor have been shown to induce TO. Exposure of young (1-100-day posthatch) medaka to aqueous solutions as low as $1.2 \mu \mathrm{g} / 1 \mathrm{o}, p^{\prime}$-DDT induced TO in males despite having relatively low estrogenic activity in the in vitro YES assay (Metcalfe et al. 2000). Atrazine at levels as low as $0.1 \mathrm{ppb}$ has induced TO in some amphibians (Hayes et al. 2003), although in other 
studies (Kloas et al. 2009) TO were not noted even at higher concentrations. Atrazine also does not competitively bind to estrogen receptors (Roberge et al. 2004). Phytoestrogens are a group of compounds that have not to date been addressed in the Potomac drainage. They may enter the aquatic environment from agricultural (Burnison et al. 2003; Hartmann et al. 2008; Kolpin et al. 2010) and industrial sources (Lundgren and Novak 2009) and may disrupt reproductive endocrine function. For example, TO have been induced in fishes through both aqueous (Kiparissis et al. 2003) and dietary (Green and Kelly 2009) exposures to selected phytoestrogens.

In conclusion, the presence of $\mathrm{TO}$ and $\mathrm{Vtg}$ in male SMB and abnormal E/T ratios of female SMB were documented at numerous sites within the Potomac River. Severity of TO was associated with agricultural land use, total number of AFO, the number of poultry houses, animal density, and permitted WWTP flow. Intersex prevalence was only associated with percent agriculture and animal density. It is likely that multiple sources are contributing to the effects observed in the Potomac River and the importance of each may differ from site to site. The seasonal differences observed indicate a need for temporal sampling at numerous sites. Measurement of both biological and chemical endpoints, in conjunction with parameters such as flow (addressing agricultural and stormwater runoff), temperature, and land-use practices (i.e., spreading manure/biosolids, spraying pesticides/herbicides, proximity of cattle to the stream), will be necessary to manage for healthy ecosystems. It is questionable whether the current TO severity and observed effects on sperm quantity/ quality at most sites studied within the Potomac drainage are alone sufficient to lead to reduced populations. However, the reproductive endocrine disruption evidenced in this study, combined with other stressors such as increased infectious disease and parasite loads, climate change, and fishing pressure, could adversely affect fish populations.

Acknowledgments This study was funded by the Chesapeake Bay Priority Ecosystems, the Toxic Substances Hydrology and Fisheries Programs, and the West Virginia Cooperative Fish and Wildlife Research Unit of the US Geological Survey. Funding was also provided by the West Virginia Departments of Natural Resources and Environmental Protection, Virginia Departments of Game and Inland Fisheries and Environmental Quality, Maryland Department of Natural Resources, and US Environ- mental Protection Agency. We appreciate the help of Jim Hedrick (WV DNR), Steve Reeser (VAGIF), John Mullican (MD DNR), Chris Guy and Fred Pinkney (FWS), and Jeff Kelble (Shenandoah Riverkeeper) for fish collections. Thanks to Deborah Iwanowicz, Jered Studinski, Emily Chambers, Eric Theall, Heather Ellery, Kathy Spring, and Darlene Bowling for field and laboratory assistance and to Bruce Eilts, Louisiana State University for CASA. We also thank John Sanseverino and Gary Sayler of the Center for Environmental Biotechnology, University of Tennessee (Knoxville, TN) for kindly providing strain BLYES and Greg Weber and the USDA National Center for Cool and Coldwater Aquaculture (Leetown, WV) for permitting us to use their facility to analyze plasma hormones. Use of trade names is for identification purposes only and does not imply endorsement by the US Government.

Open Access This article is distributed under the terms of the Creative Commons Attribution Noncommercial License which permits any noncommercial use, distribution, and reproduction in any medium, provided the original author(s) and source are credited.

\section{References}

Adams, S. M. (Ed.) (2002). Biological indicators of aquatic ecosystem stress. Bethesda: American Fisheries Society.

Aerni, H. R., Kohler, B., Rutishauser, B. V., Wettstein, F. E., Fischer, R., Giger, W., et al. (2004). Combined biological and chemical assessment of estrogenic activities and chemical assessment of estrogenic activities in wastewater treatment plant effluent. Analytical and Bioanalytical Chemistry, 378, 688-696.

Alvarez, D. A., Cranor, W. L., Perkins, S. D., Schroeder, V. L., Werner, S., Furlong, E. T., \& Brent, R. (2008a). Reconnaissance of persistent and emerging contaminants in the Shenandoah and James River basins, Virginia, during Spring 2007. U.S. Geological Survey Open-File Report 2008-1231 (p. 19).

Alvarez, D. A., Cranor, W. L., Perkins, S. D., Schroeder, V. L., Werner, S., Furlong, E. T., and Holmes, J. (2008b). Investigation of organic chemicals potentially responsible for mortality and intersex in fish of the North Fork of the Shenandoah River, Virginia, during spring of 2007. U.S. Geological Survey Open-File Report 2008-1093 (p. 16).

Alvarez, D. A., Cranor, W. L., Perkins, S. D., Clark, R. C., \& Smith, S. B. (2008c). Chemical and toxicologic assessment of organic contaminants in surface water using passive samplers. Journal of Environmental Quality, 37, 1024-1033.

Alvarez, D. A., Cranor, W. L., Perkins, S. D., Schroeder, V. L., Iwanowicz, L. R., Clark, R. C., et al. (2009). Reproductive health of bass in the Potomac, USA, drainage: part 2. Seasonal occurrence of persistent and emerging organic contaminants. Environmental Toxicology \& Chemistry, 28, 1084-1095.

Ankley, G. T., \& Johnson, R. D. (2004). Small fish models for identifying and assessing the effects of endocrinedisrupting chemicals. Institute for Laboratory Animal Research, 45, 469-483. 
Ankley, G. T., Mihaich, E., Stahl, R., Tillitt, D., Colborn, T., McMaster, S., et al. (1998). Overview of a workshop on screening methods for detecting potential (anti-)estrogenic/ androgenic chemicals in wildlife. Environmental Toxicology and Chemistry, 17, 68-87.

Baldigo, B. P., Sloan, R. J., Smith, S. B., Denslow, N. D., Blazer, V. S., \& Gross, T. S. (2006). Polychlorinated biphenyls, mercury, and potential endocrine disruption in fish from the Hudson River, New York, USA. Aquatic Science, 68, 206-228.

Bigsby, R., Chapin, R. E., Daston, G. P., Davis, B. J., Gorski, J., Gray, L. E., et al. (1999). Evaluating the effects of endocrine disruptors on endocrine function during development. Environmental Health Perspectives, 107, 613-618.

Blazer, V. S. (2002). Histopathological assessment of gonadal tissue in wild fishes. Fish Physiology and Biochemistry, 26, 85-106.

Blazer, V. S., Iwanowicz, L. R., Iwanowicz, D. D., Smith, D. R., Young, J. A., Hedrick, J. D., et al. (2007). Intersex (testicular oocytes) in smallmouth bass Micropterus dolomieu from the Potomac River and selected nearby drainages. Journal of Aquatic Animal Health, 19, 242-253.

Blazer, V. S., Iwanowicz, L. R., Starliper, C. E., Iwanowicz, D. D., Barbash, P., Hedrick, J. D., et al. (2010). Mortality of centrarchid fishes in the Potomac drainage: survey results and overview of potential contributing factors. Journal of Aquatic Animal Health, 22, 190-218.

Brayton, M. J., Denver, J. M., Delzer, G. C., \& Hamilton, P. A. (2008). Organic compounds in Potomac River water used for public supply near Washington, D.C., 2003-05. U.S. Geological Fact Sheet 2007-3085 (p. 6). Available at http://water.usgs.gov/nawqa/swqa.

Burnison, B. K., Hartmann, A., Lister, A., Servos, M. R., Ternes, T., \& Van der Kraak, G. (2003). A toxicity identification evaluation approach to studying estrogenic substances in hog manure and agricultural runoff. Environmental Toxicology and Chemistry, 22, 2243-2250.

Caldwell, D. J., Mastrocco, F., Hutchinson, T. H., Länge, R., Heijerick, D., Janssen, C., et al. (2008). Derivation of an aquatic predicted no-effect concentration for the synthetic hormone, $17 \alpha$-ethinyl estradiol. Environmental Science and Technology, 42, 7046-7054.

Denslow, N. D., Chow, M. C., Kroll, K. J., \& Green, L. (1999). Vitellogenin as a biomarker of exposure for estrogen or estrogen mimics. Ecotoxicology, 8, 385-398.

Dietrich, D. R., \& Krieger, H. O. (2009). Histological analysis of endocrine disruptive effects in small laboratory fish ( $\mathrm{p}$. 341). Hoboken: Wiley.

Filby, A. L., Neuparth, T., Thorpe, K. L., Owens, R., Galloway, T. S., \& Tyler, C. R. (2007). Health impacts of estrogens in the environment, considering complex mixture effects. Environmental Health Perspectives, 115, 1704-1710.

Gray, M. A., Niimi, A. J., \& Metcalfe, C. D. (1999). Factors affecting the development of testis-ova in medaka, Oryzias latipes, exposed to octylphenol. Environmental Toxicology and Chemistry, 18, 1835-1842.

Green, C. C., \& Kelly, A. M. (2009). Effects of the estrogen mimic genistein as a dietary components on sex differentiation and ethoxyresorufin-O-deethylase (EROD) activity in channel catfish (Ictalurus punctatus). Fish Physiology and Biochemistry, 35, 377-384.
Gross, T. M., Wieser, C. M., Sepúlveda, M. S., Wiebe, J. J., Schoeb, T. R., \& Denslow, N. D. (2002). Characterization of annual reproductive cycles for pond-reared Florida largemouth bass Micropterus salmoides floridanus. American Fisheries Society Symposium, 31, 205-212.

Guillette, L. J., Jr., Crain, D. A., Rooney, A. A., \& Pickford, D. B. (1996). Organization versus activation: the role of endocrine-disrupting contaminants (EDCs) during embryonic development in wildlife. Environmental Health Perspectives, 103, 157-164.

Hamers, T., van den Brink, P. J., Mos, L., van der Linden, S. C., Legler, J., Koeman, J. H., et al. (2003). Estrogenic and esterase-inhibiting potency in rainwater in relation to pesticide concentrations, sampling season and location. Environmental Pollution, 123, 47-65.

Harris, C. A., Hamilton, P. B., Runnalls, T. J., Vinciotti, V., Henshaw, A., Hodgson, D., et al. (2010). The consequences of feminisation in breeding groups of wild fish. Environmental Health Perspectives, 119, 306-311.

Hartmann, N., Erbs, M., Forrer, H.-R., Vogelgsang, S., Wettstein, F. E., Schwarzenbach, R. P., et al. (2008). Occurrence of zearalenone on Fusarium graminearum infected wheat and maize fields in crop organs, soil, and drainage water. Environmental Science and Technology, 42, 5455-5460.

Hayes, T., Haston, K., Tsui, M., Hoang, A., Haeffele, C., \& Vonk, A. (2003). Atrazine-induced hermaphroditism at $0.1 \mathrm{ppb}$ in American leopard frogs (Rana pipiens): laboratory and field evidence. Environ. Health Perspectives, $111,568-575$.

Hemmer, M. J., Bowman, C. J., Hemmer, B. L., Friedman, S. D., Marcovich, D., Kroll, K. J., et al. (2002). Vitellogenin mRNA regulation and plasma clearance in male sheepshead minnows (Cyprinodon variegatus) after cessation of exposure to $17 \beta$-estadiol and $p$-nonylphenol. Aquatic Toxicology, 58, 99-112.

Hemming, J. M., Allen, H. J., Thuesen, K. A., Turner, P. K., Waller, W. T., Lazorchak, J. M., et al. (2004). Temporal and spatial variability in the estrogenicity of a municipal wastewater effluent. Ecotoxicology and Environmental Safety, 57, 303-310.

Hinck, J. E., Blazer, V. S., Schmitt, C. J., Papoulias, D. M., \& Tillitt, D. E. (2009). Widespread occurrence of intersex in black basses (Micropterus spp.) from U.S. rivers, 19952004. Aquatic Toxicology, 95, 60-70.

Hutchinson, T. H., Ankley, G. T., Segner, H., \& Tyler, C. R. (2006). Screening and testing for endocrine disruption in fish-biomarkers as "sign post", not "traffic lights", in risk assessment. Environmental Health Perspectives, 114 (Suppl. 1), 106-114.

Hyndman, K. M., Biales, A., Bartell, S. E., \& Schoenfuss, H. L. (2010). Assessing the effects of exposure timing on biomarker expression using $17 \beta$-estradiol. Aquatic Toxicology, 96, 264-272.

Iwanowicz, L. R., Blazer, V. S., Guy, C. P., Pinkney, A. E., Mullican, J. E., \& Alvarez, D. A. (2009). Reproductive health of bass in the Potomac, USA, drainage: part 1. Exploring the effects of proximity to wastewater treatment plant discharge. Environmental Toxicology and Chemistry, 28, 1072-1083.

Jeffries, K. M., Nelson, E. R., Jackson, L. J., \& Habibi, H. R. (2008). Basin-wide impacts of compounds with estrogenlike activity on longnose dace (Rhinichthys cataractae) in 
two prairie rivers of Alberta, Canada. Environmental Toxicology and Chemistry, 27, 2042-2052.

Jeffries, K. M., Jackson, L. J., Ikonomou, M. G., \& Habibi, H. R. (2010). Presence of natural and anthropogenic organic contaminants and potential fish health impacts along two river gradients in Alberta, Canada. Environmental Toxicology and Chemistry, 29, 1-9.

Jenkins, R. E., \& Burkhead, N. M. (1994). Freshwater fishes of Virginia. Bethesda: American Fisheries Society.

Jenkins, J. A., Goodbred, S. L., Sobiech, S. A., Olivier, H. M., Draugelis-Dale, R. O., \& Alvarez, D. A. (2009). Effects of wastewater discharges on endocrine and reproductive function of western mosquitofish (Gambusia spp.) and implications for the threatened Santa Ana sucker (Catostomus santaanae). USGS Open-file Report 2009-1097. http://pubs.usgs.gov/of/2009/1097.

Jenkins, J. A., Eilts, B. E., Guitreau, A. M., Figiel, C. R., Draugelis-Dale, R. O., \& Tiersch, T. R. (2011). Sperm quality assessments for endangered razorback suckers Xyrauchen texanus. Reproduction, 141, 55-65.

Jobling, S., Nolan, M., Tyler, C. R., Brighty, G., \& Sumpter, J. P. (1998). Widespread sexual disruption in wild fish. Environmental Science and Technology, 32, 2498-2506.

Jobling, S., Coey, S., Whitmore, J. G., Kime, D. E., Van Look, K. J. W., McAllister, B. G., et al. (2002). Wild intersex roach (Rutilus rutilus) have reduced fertility. Biology of Reproduction, 67, 515-524.

Jobling, S., Burn, R. W., Thorpe, K., Williams, R., \& Tyler, C. (2009). Statistical modeling suggests that antiandrogens in effluents from wastewater treatment works contribute to widespread sexual disruption in fish living in English rivers. Environmental Health Perspectives, $117,797-802$.

Jones, P. D., De Coen, W. M., Tremblay, L., \& Giesy, J. P. (2000). Vitellogenin as a biomarker for environmental estrogens. Water Science and Technology, 42, 1-14.

Kavanagh, R. J., Balch, G. C., Kiparissis, Y., Niimi, A. J., Sherry, J., Tinson, C., et al. (2004). Endocrine disruption and altered gonadal development in white perch (Morone americana) from the lower Great Lakes region. Environmental Health Perspectives, 112, 898-902.

Kidd, K. A., Blanchfield, P. J., Mills, K. H., Palace, V. P., Evans, R. E., Lazorchak, J. L., et al. (2007). Collapse of a fish population after exposure to a synthetic estrogen. Proceedings of the National Academy of Sciences, 21, 8897-8901.

Kiparissis, Y., Balch, G. C., Metcalfe, T. L., \& Metcalfe, C. D. (2003). Effects of the isoflavones genistein and equol on the gonadal development of Japanese medaka (Oryzias latipes). Environmental Health Perspectives, 111, 1158-1163.

Kloas, W., Lutz, I., Springer, T., Krueger, H., Wolf, J., Holder, L., et al. (2009). Does atrazine influence larval development and sexual differentiation in Xenopus laevis? Toxicological Sciences, 107, 376-384.

Koger, C. S., Teh, S. J., \& Hinton, D. E. (2000). Determining the sensitive developmental stages of intersex induction in medaka (Oryzias latipes) exposed to 17 beta-estradiol or testosterone. Marine Environmental Research, 50, 201206.

Kolodziej, E. P., \& Sedlak, D. L. (2007). Rangeland grazing as a source of steroid hormones to surface waters. Environmental Science and Technology, 41, 3514-3520.
Kolodziej, E. P., Harter, T., \& Sedlak, D. L. (2004). Dairy wastewater, aquaculture, and spawning fish as sources of steroid hormones in the aquatic environment. Environmental Science and Technology, 38, 6377-6384.

Kolpin, D. W., Hoerger, C. C., Meyer, M. T., Wettstein, F. E., Hubbard, L. E., \& Bucheli, T. D. (2010). Phytoestrogens and mycotoxins in Iowa streams: an examination of underinvestigated compounds in agricultural basins. Journal of Environmental Quality, 39, 2089-2099.

Krisfalusi, M., \& Nagler, J. J. (2000). Induction of gonadal intersex in genotypic male rainbow trout (Oncorhynchus mykiss) embryos following immersion in estradiol17ß. Molecular Reproduction and Development, 56, 495501.

Lavado, R., Loyo-Rosales, J. E., Floyd, E., Kolodziej, E. P., Snyder, S. A., Sedlak, D. L., et al. (2009). Site-specific profiles of estrogenic activity in agricultural areas of California's inland waters. Environmental Science and Technology, 43, 9110-9116.

Liney, K. E., Jobling, S., Shears, J. A., Simpson, P., \& Tyler, C. R. (2005). Assessing the sensitivity of different life stages for sexual disruption in roach (Rutilus rutilus) exposed to effluents from wastewater treatment works. Environmental Health Perspectives, 113, 1299-1307.

Liney, K. E., Hagger, J. A., Tyler, C. R., Depledge, M. H., \& Galloway, T. S. (2006). Health effects in fish of long-term exposure to effluents from wastewater treatment works. Environmental Health Perspectives, 114, 81-89.

Luna, L. (1992). Histopathologic methods and color atlas of special stains and tissue artifacts. Gaithersburg: American Histolabs.

Lundgren, M. S., \& Novak, P. J. (2009). Quantification of phytoestrogens in industrial waste streams. Environmental Toxicology and Chemistry, 28, 2318-2323.

Martinović, D., Denny, J. S., Schmieder, P. K., Ankley, G. T., \& Sorensen, P. W. (2008). Temporal variation in the estrogenicity of a sewage treatment plant effluent and its biological significance. Environmental Science and Technology, 42, 3421-3427.

Matthiessen, P., Arnold, D., Johnson, A. C., Pepper, T. J., Pottinger, T. G., \& Pulman, K. G. T. (2006). Contamination of headwater streams in the United Kingdom by oestrogenic hormones from livestock farms. Science of the Total Environment, 367, 616-630.

Metcalfe, T. L., Metcalfe, C. D., Kiparissis, Y., Niimi, A. J., Foran, C. M., \& Benson, W. H. (2000). Gonadal development and endocrine responses in Japanese medaka (Oryzias latipes) exposed to o, $\mathrm{p}^{\prime}$-DDT in water or through maternal transfer. Environmental Toxicology and Chemistry, 19, 1893-1900.

Monosson, E., Kelce, W. R., Mac, M., \& Gray, L. E. (1997). Environmental antiandrogens: potential effects on fish reproduction and development. In R. M. Rolland, M. Gilbertson, \& R. E. Peterson (Eds.), Chemically induced alterations in functional development and reproduction (pp. 53-60). Pensacola: SETAC.

Nash, J. P., Kime, D. E., Van der Ven, L. T. M., Wester, P. W., Brion, F., Maack, G., et al. (2004). Long-term exposure to environmental concentrations of the pharmaceutical ethynylestradiol causes reproductive failure in fish. Environmental Health Perspectives, 112, 1725-1733. 
Newcombe, C. P., \& MacDonald, D. D. (1991). Effects of suspended sediments on aquatic ecosystems. North American Journal of Fisheries Management, 11, 72-82.

Nolan, M., Jobling, S., Brighty, G., Sumpter, J. P., \& Tyler, C. R. (2001). A histological description of intersexuality in the roach. Journal of Fish Biology, 58, 160-176.

Palace, V. P., Evans, R. E., Wautier, K., Baron, C., Vandenbyllardt, L., Vandersteen, W., et al. (2002). Induction of vitellogenin and histological effects in wild fathead minnows from a lake experimentally treated with the synthetic estrogen, ethynylestradiol. Water Quality Research Journal of Canada, 37, 637-650.

Palace, V. P., Evans, R. E., Wautier, K. G., Mills, K. H., Blanchfield, P. J., Park, B. J., et al. (2009). Interspecies differences in biochemical, histopathological, and population responses in four wild fish species exposed to ethynylestradiol added to a whole lake. Canadian Journal of Fisheries and Aquatic Sciences, 66, 19201935.

Panter, G. H., Thompson, R. S., \& Sumpter, J. P. (2000). Intermittent exposure of fish to estradiol. Environmental Science and Technology, 34, 2756-2760.

Roberge, M., Hakk, H., \& Larsen, G. (2004). Atrazine is a competitive inhibitor of phosphodiesterase but does not affect the estrogen receptor. Toxicology Letters, 154, 6168.

Rodgers-Gray, T. P., Jobling, S., Morris, S., Kelly, C., Kirby, S., Janbakhsh, A., et al. (2000). Long-term temporal changes in the estrogenic composition of treated sewage effluent and its biological effects on fish. Environmental Science and Technology, 34, 1521-1528.

Rosenblum, P. M., Brandt, T. M., Mayes, K. B., \& Hutson, P. (1994). Annual cycles of growth and reproduction in hatchery-reared Florida largemouth bass, Micropterus salmoides floridanus, raised on forage or pelleted diets. Journal of Fish Biology, 44, 1045-1059.

Routledge, E. J., \& Sumpter, J. P. (1996). Estrogenic activity of surfactants and some of their degradation products assessed using a recombinant yeast screen. Environmental Toxicology and Chemistry, 15, 241-248.

Routledge, E. J., Sheahan, D., Desbrow, C., Brighty, G. C., Waldock, M., \& Sumpter, J. P. (1998). Identification of estrogenic chemicals in STW effluent. 2. In vivo responses of trout and roach. Environmental Science and Technology, $32,1559-1565$.

Sanseverino, J., Eldridge, M. L., Layton, A. C., Easter, J. P., Yarbrough, J., Schultz, T. W., et al. (2009). Screening of potentially hormonally active chemicals using bioluminescent yeast bioreporters. Toxicological Sciences, 107, 122134.

Schmitt, C. J., \& Dethloff, G. M. editors. (2000). Biomonitoring of Environmental Status and Trends (BEST) Program: selected methods for monitoring chemical contaminants and their effects in aquatic ecosystems. U.S. Geological Survey Information and Technology Report USGS/BRD2000-0005 (p. 81).

Schultz, I. R., Orner, G., Merdink, J. L., \& Skillman, A. (2001). Dose-response relationships and pharmacokinetics of vitellogenin in rainbow trout after intravascular administration of $17 \alpha$-ethynylestradiol. Aquatic Toxicology, 51, 305-318.
Smeets, J. M. W., Van Holsteijn, I., Giesy, J. P., Seinen, W., \& van den Berg, M. (1999). Estrogenic potencies of several environmental pollutants, as determined by vitellogenin induction in a carp hepatocyte assay. Toxicological Sciences, 50, 206-213.

Soto, A. M., Calabro, J. M., Prechtl, N. V., Yau, A. Y., Orlando, E. F., Daxenberger, A., et al. (2004). Androgenic and estrogenic activity in water bodies receiving cattle feedlot effluent in eastern Nebraska, USA. Environmental Health Perspectives, 112, 346-352.

Sower, S. A., \& Schreck, S. B. (1982). Steroid and thyroid hormones during sexual maturation of Coho Salmon (Oncorhynchus kisutch) in seawater or fresh water. General and Comparative Endocrinology, 47, 42-53.

Stentiford, G. D., Longshaw, M., Lyons, B. P., Jones, G., Green, M., \& Feist, S. W. (2003). Histopathological biomarkers in estuarine fish species for the assessment of biological effects of contaminants. Marine Environmental Research, $55,137-159$.

Thompson, S., Tilton, F., Schlenk, D., \& Benson, W. H. (2000). Comparative vitellogenic responses in three teleost species: extrapolation to in situ field studies. Marine Environmental Research, 51, 185-189.

Thorpe, K. L., Gross-Sorokin, M., Johnson, I., Brighty, G., \& Tyler, C. R. (2006). An assessment of the model of concentration addition for predicting the estrogenic activity of chemical mixtures in wastewater treatment works effluents. Environmental Health Perspectives, 114, 90-97.

Tyler, C. R., Van Aerle, R., Hutchinson, T. H., Maddix, S., \& Trip, H. (1999). An in vivo testing system for endocrine disruptors in fish early stages using induction of vitellogenin. Environmental Toxicology and Chemistry, 18, 337-347.

Tyler, C. R., Jage, A., Paull, G. C., Katsu, Y., \& Iguchi, T. (2007). The roach (Rutilis rutilis) as a sentinel for assessing endocrine disruption. Environmental Sciences, 14, 235-253.

van Aerle, R., Nolan, M., Jobling, S., Christiansen, L. B., Sumpter, J. P., \& Tyler, C. R. (2001). Sexual disruption in a second species of wild cyprinid fish (the gudgeon, Gobio gobio) in United Kingdom freshwaters. Environmental Toxicology and Chemistry, 20, 2841-2847.

Van den Belt, K., Verheyen, R., \& Witters, H. (2003). Comparison of vitellogenin responses in zebrafish and rainbow trout following exposure to environmental estrogens. Ecotoxicology and Environmental Safety, 56, 271-281.

Vine, E., Shears, J., van Aerle, R., Tyler, C. R., \& Sumpter, J. P. (2005). Endocrine (sexual) disruption is not a prominent feature in the pike (Esox lucius), a top predator, living in English waters. Environmental Toxicology and Chemistry, 24, 1436-1443.

Wheeler, J. R., Gimeno, S., Crane, M., Lopez-Juez, E., \& Morritt, D. (2005). Vitellogenin: a review of analytical methods to detect (anti) estrogenic activity in fish. Toxicology Mechanisms and Methods, 15, 293-306.

Yamamoto, T. (1969). Sex differentiation. In W. S. Hoar \& D. J. Randall (Eds.), Fish physiology (pp. 117-177). New York: Academic.

Yambe, H., Munakata, A., Aida, K., Fusetani, N., \& Kitamura, S. (2004). Reproductive cycle of smallmouth bass in Lake Akimoto. Nippon Suisan Gakkaishi, 70, 896-901. 
Yoder, C. O., \& Rankin, E. T. (1998). The role of biological indicators in a state water quality management process. Environmental Monitoring and Assessment, 51, 61-88.

Yonkos, L. T., Fisher, D. J., Van Veld, P. A., Kane, A. S., McGee, B. L., \& Staver, K. W. (2010). Poultry litterinduced endocrine disruption in fathead minnow, sheeps- head minnow, and mummichog laboratory exposures. Environmental Toxicology and Chemistry, 29, 1-13.

Young, W. F., Whitehouse, P., Johnson, I., \& Sorokin, N. (2002). Proposed predicted no effect concentrations (PNECs) for natural and synthetic steroid oestrogens in surface waters. Environment Agency $R \&$ D Technical Report P2-T04/1 (pp. 93-95). Bristol: England and Wales Environment Agency 